This is the author's version of a work that was published in the following source:

Jochem, P.; Gómez Vilchez, J. J.;

Ensslen, A.; Schäuble, J.; Fichtner, W. (2018).

Methods for forecasting the market penetration of electric drivetrains in the passenger car market ${ }_{\square}$.

Transport reviews, 38 (3), 322-348. doi:10.1080/01441647.2017.1326538

Please note: Copyright is owned by the author(s) and / or the publisher. The commercial use of this copy is not allowed. 


\title{
Methods for Forecasting the Market Penetration of Electric Drivetrains in the Passenger Car Market
}

\author{
Current car technologies will not solve upcoming challenges of mitigating \\ greenhouse gas emissions in road transport. Projections of the market penetration \\ by alternative drive train technologies are controversial regarding both forecast \\ market shares and applied scientific methods. Accepting this latter challenge, we \\ provide a (so far missing) overview of methods applied in this field and give \\ some recommendations for further work. \\ Our focus is to classify the applied methods into a convenient pattern and to \\ analyse models from the recent scientific literature which consider the \\ electrification of light-duty vehicles. We differentiate the following bottom-up \\ approaches: Econometric models with disaggregated data (such as discrete \\ choice), and agent-based simulation models. The group of top-down models are \\ subdivided into econometric models with aggregated data (e.g. vehicle stock \\ data), system dynamics, as well as integrated assessment models with general \\ equilibrium models. It becomes obvious that some methods have a stronger \\ methodological background whereas others require comprehensive data sets or \\ can be combined more flexibly with other methods. Even though there is no \\ dominant method, we can identify a trend in the literature towards data-driven \\ hybrid approaches, which considers micro and macro aspects influencing the \\ market penetration of electric vehicles.
}

Keywords: market penetration, electric vehicles, modelling, methods, diffusion, forecasting, alternative drivetrains

\section{Introduction}

Driven by the fast development of emerging economies, a doubling of the global fleet of light-duty vehicles (LDV) and fuel demand by 2050 is expected in business-as-usual scenarios (IEA (International Energy Agency), 2016a). When these LDV are still based on conventional drivetrain technology, this development is a strong contradiction to the current objectives of mitigating greenhouse gas (GHG) emissions in order to limit 
global warming below the two-degree target, i.e. halve global GHG emissions until 2050 (IPCC, 2014). Currently, the transport sector, as the second largest emitter of the main $\mathrm{GHG}$, carbon dioxide $\left(\mathrm{CO}_{2}\right)$, increases its share significantly compared to the key player, the energy sector (IPCC, 2014). Therefore, its responsibility to reverse this trend is substantial. However, transport has not yet been in the focus of the political agenda (cf. Creutzig et al., 2015). Electric drivetrains (i.e. hybrid electric vehicles (HEV), plugin hybrid electric vehicles (PHEV), pure battery electric vehicles (BEV), and fuel-cell electric vehicles (FCEV)) - besides the "servitization" of mobility - are considered backbones for sustainable transport systems. A successful market penetration of (partially) electrified vehicles seems highly probable (IEA (International Energy Agency), 2016b).

A preferably precise market forecast for alternative drivetrains is crucial for several decision makers in the automotive and energy industries as well as in politics. However, current predictions show diverse results (Kay, Hill, \& Newman, 2013) but have become a very actively investigated research topic with a multitude of applied methods (Jong, Fox, Daly, Pieters, \& Smit, 2004). According to most studies, the market forecast is (still) associated with unavoidable uncertainties and may in the early market phase depend strongly on policy incentives (Lévay, Drossinos, \& Thiel, 2017). After a market share of around 2\%, a distinct market take-off might occur (Golder \& Tellis, 1997). Hence, at the current market phase the reliability of study results relies on many hazards and does not imply any unique solution. Nevertheless, the scientific community is in charge of providing suitable methods for generating these forecasts. In the following, we therefore give an overview of forecasting methods currently applied in this research area by classifying them and highlighting their strengths and weaknesses (similar to Anowar, Eluru, \& Miranda-Moreno (2014) or Potoglou \& 
Kanaroglou (2008)). Our results might be used by researchers to find an appropriate method for answering their specific questions or by decision makers to evaluate the reliability of applied methods.

We structured our paper in accordance with the main methodological dimensions and start with a short introduction to the main terminology and methodological background before dedicating further sections to the specific methods. Section 3 gives an overview of current research into bottom-up models such as disaggregated econometric models (3.1), and agent-based models (ABM) (3.2). Section 4 deals with top-down models classified into econometric models (4.1), system dynamics (SD) models (4.2), integrated assessment models, and general equilibrium models (4.3). Finally, Section 5 presents some hybrid models, which are combinations of bottom-up and top-down models. A discussion and a section for conclusions complete the paper.

\section{Proposed Classification of Methods}

Methods applied in our research field can be classified by a multitude of dimensions. We base our classification on the bottom-up and top-down model dimensions (cf. Figure 1), which is a standard approach in the energy field (cf. Herbst, Toro, Reitze, \& Jochem, 2012).

- Bottom-up models represent reality by aggregating heterogeneous characteristics of technological or socioeconomic activities and processes. They are calibrated with disaggregated data and mostly focus on a single economic sector. The methods are based on simulations or optimization techniques.

- Top-down models apply macroeconomic theory, econometric and optimization techniques with aggregate economic variables. They rely on historical data of 
consumption, prices, incomes, or factor costs and may consider all main economic sectors such as energy, transportation, agriculture, and industry. Some top-down models incorporate technology data, thus narrowing the gap to bottom-up models.

- Hybrid models are a combination of bottom-up and top-down models, thus representing an example of mixed modeling (Hourcade, Jaccard, Bataille, \& Ghersi, 2006).

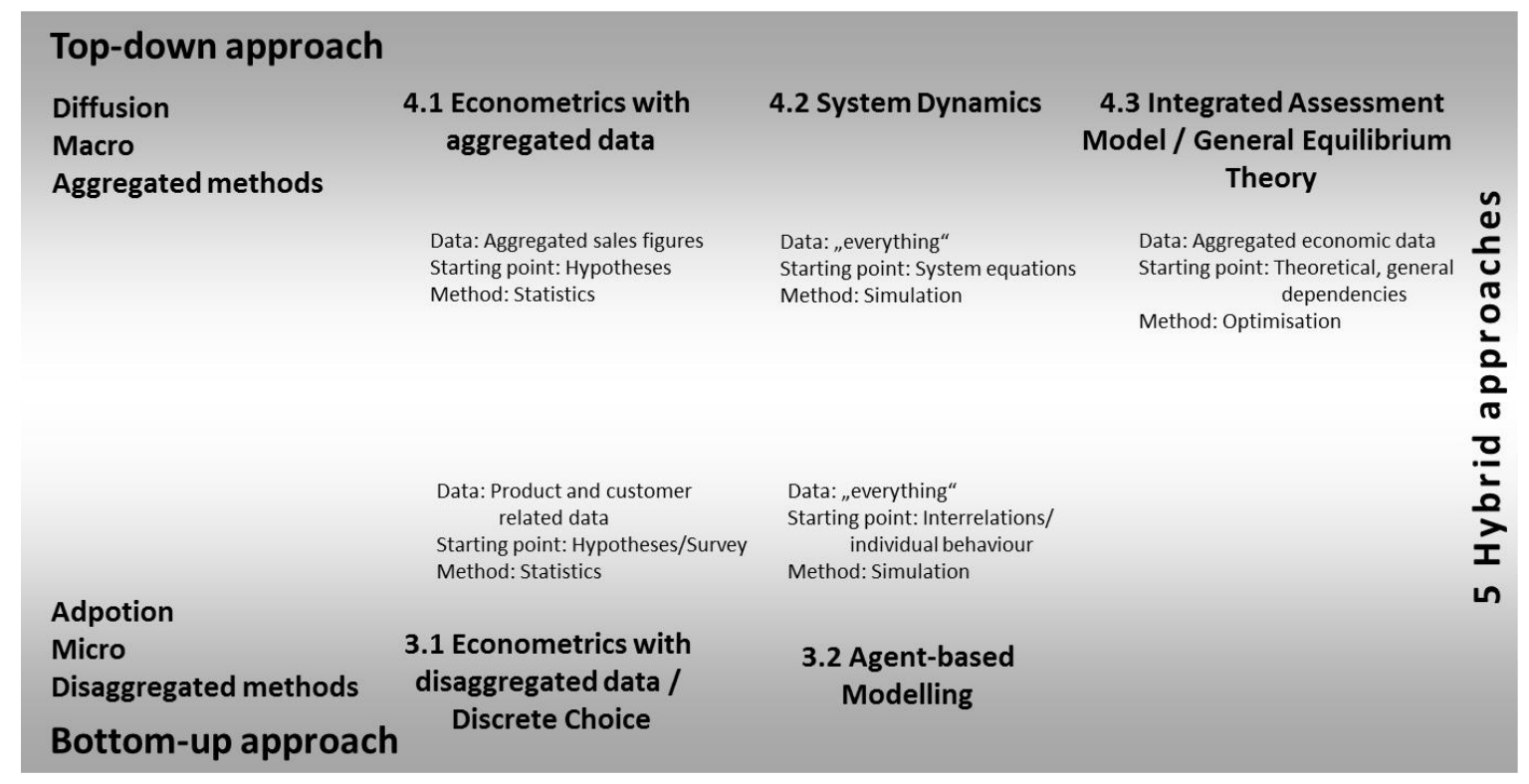

Figure 1: Outline of the considered methodology

Besides this general modeling differentiation, the availability of data has a crucial influence on the choice of methodology. The most apparent influence on the modeling technique is the aggregation level of the data. Furthermore, the quality of the data is highly relevant. In the transport sector, most data is available only on a monthly or annual basis. An exception includes e.g. fuel prices, which are available at least on a daily basis. While aggregated data such as vehicle sales are often publicly available, detailed data availability is often restricted to commercial users. Especially data on customer requirements is costly, highly sensible, and difficult to access. The quality of 
each dataset should be crucially evaluated with respect to data consistency and reliability.

Another significant peculiarity in our field of investigation is the heterogeneity of car purchase decisions. Actors in different submarkets have specific objectives: Whereas, for company fleet vehicles, a rational decision rule is prevalent for the purchase decision (Brand, Cluzel, \& Anable, 2017), individual purchase decisions in the company car market are diverse. Private customers, who in Germany represent about $40 \%$ of the whole LDV market (Gnann, Plötz, Funke, \& Wietschel, 2015), have individual preferences and show even aspects of bounded rationality in their decisions, which highly rely on (spontaneous) heuristics and cognitive rules of thumb but hardly on analytical deliberation (de Haan, Mueller, \& Scholz, 2009). Consequently, a simple reproduction of the vehicle purchase decision seems to be impossible.

Nevertheless, pure cost optimizing approaches are sometimes used for giving a first approximation of the market potential of an alternative technology (Pfahl, Jochem, \& Fichtner, 2013). Many car ownership models refer to this input parameter, which is often based on the total cost of ownership (TCO) or the life-cycle cost approach. Hence, all costs such as taxes, maintenance and investment during the whole life cycle are considered and converted into comparable units such as euros per year. These comparisons usually rely on assumptions (e.g., for annual mileage, fuel price prognosis for several years, etc.) which have a significant impact on results. Cost-optimizing approaches are often applied in energy system modeling (Densing, Turton, \& Bäuml, 2012; Grahn et al., 2009; Gül, Kypreos, Turton, \& Barreto, 2009; D. McCollum, Yang, Yeh, \& Ogden, 2012; Pietzcker et al., 2014).

\section{Bottom-up Models}

In our research field, bottom-up models have a long tradition - mainly in econometrics 
(cf. Section 3.1). A more recent development is agent-based modeling (ABM) (cf. Section 3.2). Mixed bottom-up models are applied, too (Mock, Hülsebusch, D., Ungethüm, J., \& Schmid, S.A., 2010; Propfe, Kreyenberg, Wind, \& Schmid, 2013; Shafiei et al., 2012; Sullivan, Salmeen, \& Simon, 2009; Vliet, Vries, Faaij, Turkenburg, \& Jager, 2010).

\subsection{Econometric Models with Disaggregated Data}

In this section, we focus on methods from applied microeconometrics.

\section{History}

McFadden (2000) provides an overview of the history of microeconometric analysis of choice behaviour by consumers who face discrete economic alternatives. Research concerning transportation decisions has been further enriched afterwards by Abou-Zeid and Ben-Akiva (2014). Furthermore, discrete choice models were widely applied to microeconometric decisions concerning vehicle choice including alternative fuels and drivetrain technologies (Achtnicht, Bühler, \& Hermeling, 2012; Brownstone, Bunch, \& Train, 2000; Brownstone \& Train, 1998; Bunch, Bradley, Golob, Kitamura, \& Occhiuzzo, 1993; Dagsvik, Wennemo, Wetterwald, \& Aaberge, 2002; Daziano, 2015; Daziano \& Achtnicht, 2014; Daziano \& Bolduc, 2011; Hensher, Beck, \& Rose, 2011; Horne, Jaccard, \& Tiedemann, 2005; Train, 1986). Another recent development is the random regret minimization (RRM) model introduced by Chorus, Arentze, \& Timmermans (2008).

The economists' standard microeconometric model, a theory of rational choice, has been further developed by integrating psychological factors that are included in decision-making (Moshe Ben-Akiva et al., 1999). In psychological theories of the choice process, the individual is less organized, more adaptive and imitative. Attitudes 
play a major role (Kahneman \& Tversky, 2000). These are determined by affect and motivation and influence perceptions that feed into the choice process. Utility maximization or, alternatively, regret minimization by individuals is reduced to one of many factors in the decision-making environment. Its influence is often constrained by context effects, emotion, and errors in perception and judgement (Gärling, 1992; Loewenstein, 1996; Svenson, 1979). Heuristic rules seem appropriate to describe decision-making processes of humans. The psychological point of view concerning the adoption of alternative fuel vehicles has been widely studied during the last years (Axsen, TyreeHageman, \& Lentz, 2012; Egbue \& Long, 2012; Peters, Gutscher, \& Scholz, 2011; Schuitema, Anable, Skippon, \& Kinnear, 2013).

\section{Main characteristics and assumptions}

According to Ben-Akiva et al. (2002), domains of choice research can be classified by (1) Behavioural Choice Analysis, (2) Predictive Choice Models, and (3) Random Utility Models. Predictive choice models focus mainly on quantitative modeling in order to use relevant results for predictions that are of particular interest in economics, marketing, planning, and engineering. According to Ben-Akiva et al. (2002), behavioral choice analysis deconstructs the choice process by concentrating on revealing irregularities and idiosyncratic features of choice behavior. Modeling of choice behavior by incorporating cognitive processes with unobserved or latent elements of choice processes in predictive choice models, e.g. attitudes and perceptions within structural equation models, is done by hybrid choice models (Abou-Zeid \& Ben-Akiva, 2014), hybrid discrete choice models (Raveau, Yáñez, \& Ortúzar, 2012) or integrated choice and latent variable models (Bhat \& Dubey, 2014; Vij \& Walker, 2016). The main assumption is that there is a rationale behind all choices, which can be approximated by utility maximization or, alternatively, regret minimization. Due to the applied statistical methods, data 
requirements are substantial.

\section{Literature}

There is a comprehensive literature on disaggregated econometric models in our research field. We therefore focus in Table 1 on more recent models. A problemfocused introduction is given by Daziano \& Achtnicht (2014) and further literature can be found in (Al-Alawi \& Bradley, 2013). 
Table 1: Selected literature on econometric models with disaggregated data

\begin{tabular}{|c|c|c|c|c|}
\hline Authors & Jurisdiction & $\begin{array}{l}\text { Time } \\
\text { horizon }\end{array}$ & Technology & Key features \\
\hline $\begin{array}{l}\text { Plötz et al., } \\
2014\end{array}$ & Germany & - & BEV, PHEV & $\begin{array}{l}\text { Consumer-choice modeling is applied focusing on early adopters of } \\
\text { EVs. }\end{array}$ \\
\hline $\begin{array}{l}\text { Lopes et al., } \\
2014\end{array}$ & $\begin{array}{l}\text { Portugal / } \\
\text { Lisbon }\end{array}$ & 2020 & EV & $\begin{array}{l}\text { A rule-based screening methodology with simple non-compensatory } \\
\text { rules is developed. Results suggest that, currently, the diffusion of EV } \\
\text { in Lisbon Metropolitan Area is very restricted. }\end{array}$ \\
\hline $\begin{array}{l}\text { Glerum et al., } \\
2014\end{array}$ & Switzerland & - & BEV & $\begin{array}{l}\text { A hybrid choice model based on a stated preference survey was } \\
\text { specified for car purchase decisions which includes a forecasting } \\
\text { analysis. As a result, they give certain properties of target customers. }\end{array}$ \\
\hline $\begin{array}{l}\text { Daziano and } \\
\text { Achtnicht, } \\
2014\end{array}$ & Germany & - & $\begin{array}{l}\text { HEV, } \\
\text { LPG/CNG, } \\
\text { biofuel, BEV, } \\
\text { FCEV }\end{array}$ & $\begin{array}{l}\text { Bayes estimates of a multinominal probit model with fully flexible } \\
\text { substitution patterns are used in order to forecast consumer response to } \\
\text { ultralow emission vehicles. Stated preference data from a Germany- } \\
\text { wide survey of potential } 600 \text { light-duty vehicle buyers are used to } \\
\text { estimate choice probabilities of different drivetrain alternatives. }\end{array}$ \\
\hline $\begin{array}{l}\text { Rezvani et al., } \\
2015\end{array}$ & $\begin{array}{l}\text { US, UK, } \\
\text { Denmark, } \\
\text { Germany, } \\
\text { Belgium, } \\
\text { Netherlands, } \\
\text { China }\end{array}$ & - & BEV, PHEV & $\begin{array}{l}\text { A literature review is provided. The factors influencing consumer } \\
\text { intentions to purchase EVs are the focus of this paper. }\end{array}$ \\
\hline
\end{tabular}

\section{Discussion}

In order to classify the econometric-based electric vehicle adoption research of the last years, the literature from Table 1 and from Rezvani et al. (2015) are classified according to the scheme on domains of choice research by Ben-Akiva et al. (2002). As our study tries to identify methods to forecast electric vehicle market shares, we extended the framework by integrating (representative) market forecast models into the scheme (cf. Figure 2). 


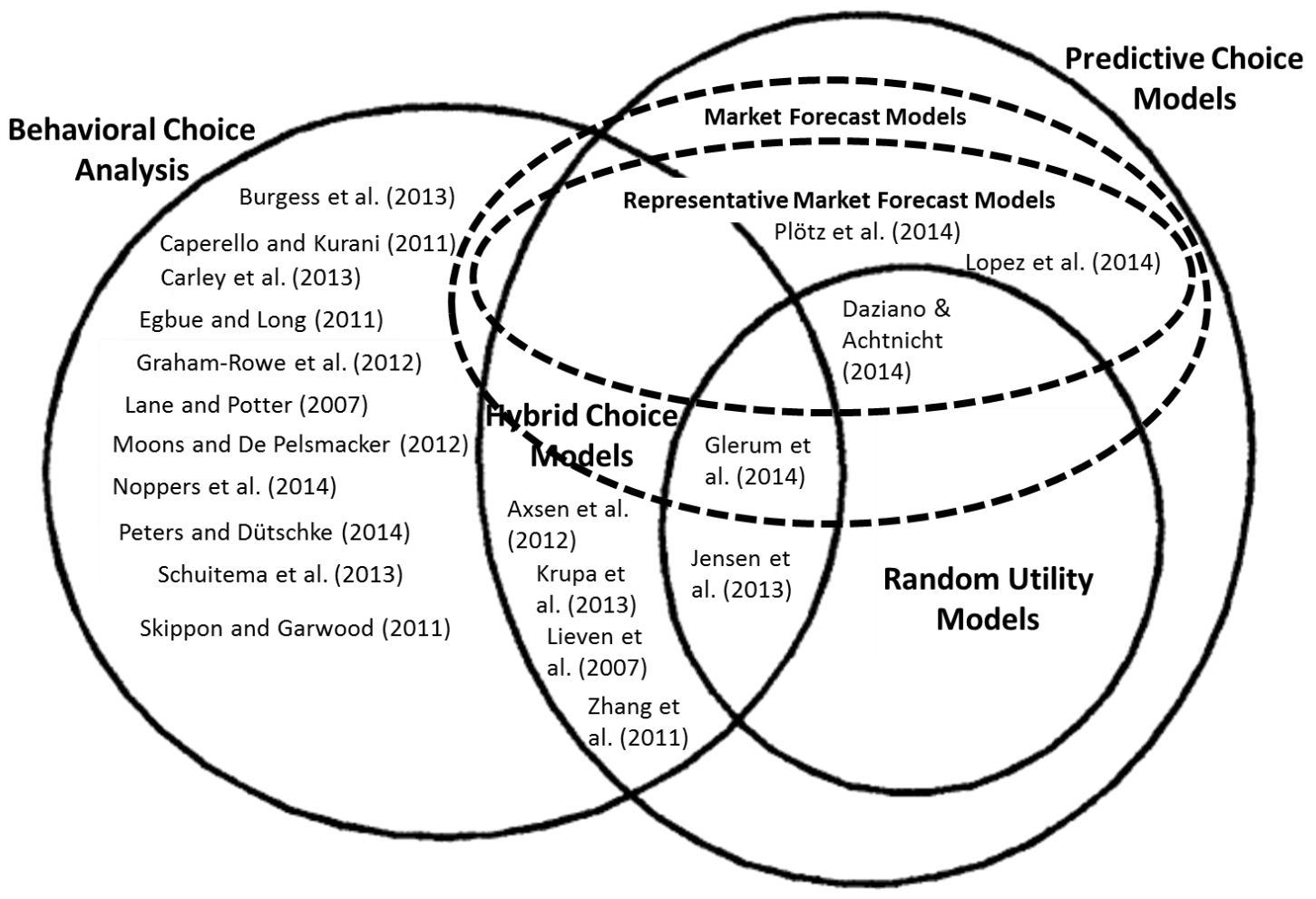

Figure 2: Categorization of econometric-based adoption studies of electric vehicles based on Ben-Akiva et al. (2002)

From Figure 2 follows that there are many studies on adoption of electric vehicles particularly accounting for psychological factors such as attitudes and perceptions. However, there is a lack of adoption studies incorporating these psychological factors in order to perform market forecasts.

Table 2: Advantages and disadvantages of disaggregated econometric models

\begin{tabular}{|c|c|}
\hline ADVANTAGES & DISADVANTAGES \\
\hline $\begin{array}{l}\text { - } \begin{array}{l}\text { Market diffusion scenarios based on } \\
\text { revealed or stated preferences can be } \\
\text { empirically modeled already at an early }\end{array} \\
\text { market stage by applying inferential } \\
\text { statistics. } \\
\text { Market behavior can be explained by } \\
\text { aggregating the single decisions of } \\
\text { individuals taken from discrete choice } \\
\text { models. Therefore, (regional) } \\
\text { heterogeneities might be taken into account. } \\
\text { Desirable combination of theory and } \\
\text { empirical basis. }\end{array}$ & 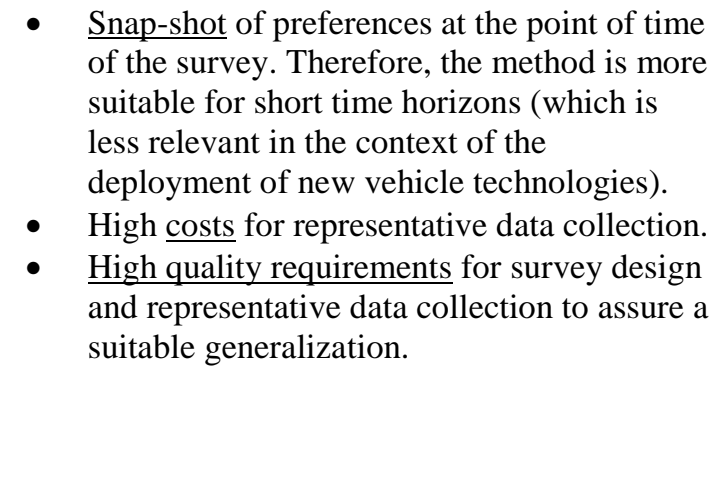 \\
\hline
\end{tabular}

Advantages of disaggregated econometric data and models (cf. Table 2) include that diffusion of innovations can be modeled already at an early market stage. 
Furthermore, market behavior can be explained as diffusion is represented by an aggregation of individual choices. However, the preferences collected during surveys only represent snap-shots accompanied by high costs and quality standards for collecting representative data.

\subsection{Agent-based Modeling}

Existing reviews of diffusion models such as those presented by Al-Alawi and Bradley (2013) or Coffman, Bernstein, and Wee (2015) have revealed an increasing interest in the possibilities provided by ABM in this field of research.

\section{History}

$\mathrm{ABM}$ and individual-based simulation have its origin in the late 1940 when computational analysis became practicable for research disciplines. Its roots can be found in the modeling of cellular automata, as well as in the various fields of artificial intelligence (G. N. Gilbert, 2008). ABM is mainly based on its basic components, the agents (and their agent theory), the representation of the complexity of the modeled system (e.g. interaction topology), and the emerging states after simulation of the model and has been developed simultaneously in many research fields ranging from social and economic sciences to natural sciences. Consequently, there is no unique definition of ABM.

\section{Main characteristics and assumptions}

The main objective of simulation is describing and subsequently analyzing the (global) behavior of dynamic complex systems by means of imitation of real processes or systems over a specified period of time. If these simulations represent systems that are characterized by decentralized and distributed data as well as asynchronous 
computations (absence of a central control), it is preferable to use an agent-based approach. One main advantage of ABM is their (up- and down-) scalability and thus an accordingly easy disassembly of the complex system. ABM consists of three main components: Agents, an interconnecting structure, and their context. The context comprises all necessary external information which is not stored within the agents and is not to be confused with the environment outside of the system. It is defined by the totality of the agents of the system, their individual characteristics, system rules, existing goods, and sensors. Although the definition of agents varies between research fields, the main properties of agents are: Individuality and ability to communicate (Hewitt, 1977), cognition of their environments, proactivity, and independence (Wooldridge \& Jennings, 1995). Agents may possess static or changing roles (which requires a certain ability to learn) and act charitably, competitively or in a team. The interactions of the agents in their particular contexts may lead to a global behavior (which may be regularities or patterns) within the model. This emergence allows identifying regularities for the modeled complex system.

With these properties, $\mathrm{ABM}$ and its agents are predestined to simulate human relations and behavior (Rai \& Henry, 2016). These flexibilities in modeling agents individually provides a wide range of opportunities to represent distinct behaviors such as strategies, bounded rationality or incomplete information (Sycara, 1998). Consequently, the data requirement is dependent on the research focus.

\section{Literature}

Recently, the advantages of ABM have been used widely to forecast the market penetration of alternative drivetrains in the passenger car market. One cornerstone for these diffusion models was provided by Kiesling, Günther, Stummer, \& Wakolbinger, (2012). Depending on the objective, simulations run with different time horizons from 
about 10 years (cf. Table 3). Many ABM diffusion models discuss PHEV adoption (Cui et al., 2010; Eppstein, Grover, Marshall, \& Rizzo, 2011; Stephens, 2010; Sullivan et al., 2009). Diffusion of BEV and other drivetrains (de Haan et al., 2009; Schwoon, 2006), other fuels (e.g. Vliet et al., 2010) or even in combination with charging infrastructure (Gnann, 2015) are analyzed. Many ABM focus on a low level of aggregation and on local residential diffusion (e.g. Cui et al., 2010) or regions with restricted scope (e.g. Knox County (Cui et al., 2010), Boston (Brown, 2013), Michigan (Stephens, 2010), Iceland (Shafiei et al., 2012), Germany (Propfe et al., 2013) or Hawaii (Coffman et al., 2015)). Some ABM are based on the individual parameterization of the agents (e.g. budgets, recharging concerns, previously owned cars) and the vehicles (e.g. size, performance, and brand) (Mock et al., 2010; Propfe et al., 2013; Shafiei et al., 2012; Sullivan et al., 2009). Garcia (2007) uses an individual hedonic demand model developed by Boyd et al. (1980). Several ABM included a multitude of external impacts on the purchase decision like spatial (Eppstein et al., 2011) and neighborhood (Cui et al., 2010) effects, social networks (de Weerdt, Zhang, \& Klos, 2012), media influences (Eppstein et al., 2011), and infrastructure (Schwoon, 2006). ABM allows integrating multiple actors (besides the agent group of adopters) that may influence the market penetration. Such actors are e.g. car manufacturers and the government (Garcia, 2007). These additional agents equally pursue an objective and have a range of possible actions that influence the simulation run. In several of the reviewed ABM, market penetration is a secondary aim. Other objectives are e.g., the impact of the new fleet composition on the energy system (Cui et al., 2010) and on GHG emissions (Stephens, 2010) or determining the effect of car purchase incentives (de Haan et al., 2009). Due to the object-based architecture of ABM, they are often applied in hybrid models (e.g. Brown, 2013; Kieckhäfer, 2013). 
Table 3: Selected literature on agent-based models of adoption

\begin{tabular}{|c|c|c|c|c|}
\hline Authors & Jurisdiction & $\begin{array}{l}\text { Time } \\
\text { horizon }\end{array}$ & Technology & Key features \\
\hline Brown, 2013 & $\begin{array}{l}\text { Boston } \\
\text { metropolitan } \\
\text { area }\end{array}$ & $2009-2030$ & PHEV, BEV & $\begin{array}{l}\text { A mixed logistic regression and an agent-based model are } \\
\text { combined to simulate social network interactions. Battery } \\
\text { costs have a relatively small impact on EV diffusion in } \\
\text { comparison to policy, range, miles per gallon (MPG), and } \\
\text { vehicle miles traveled. }\end{array}$ \\
\hline $\begin{array}{l}\text { Propfe et al., } \\
2013\end{array}$ & Germany & $2010-2030$ & $\begin{array}{l}\text { FCEV, BEV, } \\
\text { PHEV, HEV }\end{array}$ & $\begin{array}{l}\text { The analysis is based on three fleet scenarios within the } \\
\text { VECTOR21 (vehicle technology scenario model) model. } \\
\text { Results highlight that EV penetration depends mainly on } \\
\text { external conditions. }\end{array}$ \\
\hline $\begin{array}{l}\text { Shafiei et al., } \\
2012\end{array}$ & Iceland & $2012-2030$ & $\mathrm{EV}$ & $\begin{array}{l}\text { The model is based on a vehicle choice algorithm that } \\
\text { accounts for social influences and consumers' attractiveness } \\
\text { for vehicle attributes. The evaluation focuses on the effects of } \\
\text { fuel and vehicle prices as well as charging concerns. As a } \\
\text { conclusion, successful adoption of EV needs policy support in } \\
\text { adverse scenarios. }\end{array}$ \\
\hline $\begin{array}{l}\text { Eppstein et al., } \\
2011\end{array}$ & US & 25 years & PHEV & $\begin{array}{l}\text { A spatial vehicle consumer choice model is developed which } \\
\text { explores sensitivities and nonlinear interactions of the vehicle } \\
\text { purchase decision. The results indicate that PHEV market } \\
\text { share can be increased by presenting estimates of expected } \\
\text { lifetime fuel costs to customers. }\end{array}$ \\
\hline $\begin{array}{l}\text { Zhang et al., } \\
2011\end{array}$ & US & $\begin{array}{l}\text { multiple time } \\
\text { horizons }\end{array}$ & $\begin{array}{l}\text { alternative fuel } \\
\text { vehicles, PHEV, } \\
\text { BEV }\end{array}$ & $\begin{array}{l}\text { A choice-based conjoint analysis is used to elicit } \\
\text { heterogeneous consumer preference. As a core result, positive } \\
\text { word-of-mouth messages lead to a higher willingness to pay } \\
\text { for alternative fuel vehicles. }\end{array}$ \\
\hline Cui et al., 2010 & Knox County, & 2011-2020 & PHEV & $\begin{array}{l}\text { The analysis is based on a spatial distribution of car ownership } \\
\text { at local residential household level. The main result highlights } \\
\text { that neighborhoods with multiple PHEV may require changes } \\
\text { in distribution grid infrastructure. }\end{array}$ \\
\hline Stephens, 2010 & Michigan & $2010-2030$ & PHEV & $\begin{array}{l}\text { This study is based on travel demand and statistical } \\
\text { information on travel by U.S. drivers and highlights the } \\
\text { electricity and fuel demand and the resulting GHG emissions. }\end{array}$ \\
\hline Vliet et al., 2010 & $\begin{array}{l}11 \text { populations } \\
\text { of motorists }\end{array}$ & 20 years & $\begin{array}{l}6 \text { fuels blends } \\
\text { from } 6 \text { feedstocks }\end{array}$ & $\begin{array}{l}\text { The model is based on heuristics and considers different } \\
\text { vehicles as well as social attributes. As a result, price is the } \\
\text { main decision criterion for motorists. }\end{array}$ \\
\hline
\end{tabular}




\begin{tabular}{|c|c|c|c|c|}
\hline $\begin{array}{l}\text { de Haan et al., } \\
2009\end{array}$ & Switzerland & - & $\begin{array}{l}\text { fuel-efficient and } \\
\text { highly inefficient } \\
\text { cars }\end{array}$ & $\begin{array}{l}\text { Consumer agents possess price elasticities and behavioral } \\
\text { options to react to feebates. These systems seem to } \\
\text { successfully reduce energy consumption and } \mathrm{CO}_{2} \text { emissions. }\end{array}$ \\
\hline $\begin{array}{l}\text { Stephan and } \\
\text { Sullivan, } 2009\end{array}$ & US & $2015-2040$ & PHEV & $\begin{array}{l}\text { Two types of agents are considered: Vehicle owners and } \\
\text { hydrogen fuel suppliers. Results show that subsidies are } \\
\text { critical and sales tax exemptions can help if manufacture } \\
\text { subsidies are in place. }\end{array}$ \\
\hline Garcia, 2007 & US & - & PHEV, BEV & $\begin{array}{l}\text { The combination of a consumer behavior model and an ABM } \\
\text { is applied in order to analyze the impact of manufacturers' } \\
\text { product design and vehicle offerings on market development. }\end{array}$ \\
\hline
\end{tabular}

\section{Discussion}

On the one hand, the lack of a commonly acknowledged definition of ABM leads to a diversity of models, which makes an objective evaluation challenging. On the one hand, this flexibility allows a comprehensive adjustment to the system under evaluation or even to extend the model by other methods (hybrid model). The interactions among agents and with the environment (including learning) are in the focus of this methodology, which allows to represent decision patterns close to reality (cf. Table 4).

Table 4: Advantages and disadvantages of agent-based modeling

\begin{tabular}{|c|c|}
\hline ADVANTAGES & DISADVANTAGES \\
\hline $\begin{array}{l}\text { - Specific and heterogeneous market behavior } \\
\text { of different actors can be considered } \\
\text { (behaviors can be defined discretely and } \\
\text { may change over time). } \\
\text { - Modular character of the methodology } \\
\text { allows combinations with other methods } \\
\text { into hybrid models. } \\
\text { - Learning and strategies can be applied. } \\
\text { - Relationships and interactions of the } \\
\text { systems' actors can be modeled precisely. }\end{array}$ & $\begin{array}{l}\text { - The freedom in modeling leads to less } \\
\text { transparent methods. } \\
\text { Models tend to be incomprehensible, and } \\
\text { complex computational modeling } \\
\text { experience is required compared to typical } \\
\text { formal proofs; there is no standardized } \\
\text { toolbox, yet. } \\
\text { Due to a weak theoretical background it is } \\
\text { hard to follow all assumptions and further } \\
\text { model specifications. } \\
\text { Data basis is in most models too weak for } \\
\text { calibrating the behavioral rules of agents. }\end{array}$ \\
\hline
\end{tabular}

\section{Top-down Models}

We subdivide the section into econometric models (Section 4.1), system dynamics models (Section 4.2), and integrated assessment and general equilibrium models 
(Section 4.3). Mixtures of top-down approaches are not known.

\subsection{Econometric Models with Aggregated Data}

In this section, we focus on methods from applied macroeconometrics.

\section{History}

Following early econometric work on business cycles, econometric activity unfolded at the beginning of the last century (Morgan, 2008) and was institutionalized in the 1930s. It aimed "at a unification of the theoretical-quantitative and the empirical-quantitative approach to economic problems" (Frisch, 1933, p. 1). Important original contributions had been made by, among others, Tinbergen (1937), Haavelmo (1944), and Koopmans (1949). Over the years, econometrics has arguably become the dominant method within empirical economics.

\section{Main characteristics and assumptions}

A variety of econometric methodologies has been proposed (cf. Gilbert, 1986; Pagan, 1987; Hoover, 2005). With a focus on market penetration of electric vehicles, four key aspects of aggregate econometrics modeling are highlighted. (1) Forecasting, which is a main purpose of most work in econometrics (Intriligator, 1983). (2) Time series, which include causal models and 'sophisticated' extrapolative models, which are based on techniques popularized as the Box-Jenkins approach (Box \& Jenkins, 1976). (3) Stochastic modeling, which acknowledges the random nature of economic variables explicitly in models and relies on statistical inference (Spanos, 1999). (4) Data quality, which is always a crucial issue in econometrics (Morgenstern, 1965; Griliches, 1986).

For multi-country forecasts, three potential problems can be highlighted with regards to vehicle-related data: Short available time horizon for alternative drivetrains, 
lack of harmonization of variables' definitions, and changes over time in the data collection method by the statistical agency.

\section{Literature}

Two lines of application of aggregate econometrics in the car market are considered: Car ownership projections and choice of vehicle types. Aggregate econometric models have been extensively used to forecast car ownership at the national level (Jong et al., 2004). Modelers have long been aware of car market saturation and have consequently employed nonlinear sigmoid functions to capture how car ownership changes over time. Initially, the modeler determines whether a symmetric curve should be applied. The former results in the Verhulst growth or logistic (regression) model (Verhulst, 1838). In theory, many different asymmetric S-shaped growth curves could be used: A common one is the Gompertz growth curve used by e.g., Dargay et al. (2007). In our context of diffusion of innovations, the Bass model (Bass, 1969, 2004) is often applied. Relaxation of its most restrictive assumptions has led to several variants of the Bass model. Some authors even extend the Bass model with disaggregated data (e.g. Higgins et al., 2012). The task described in this paper, however, is a different one, as we are not only interested in forecasting a particular level of total car stock, but in the different market shares by type of car technology. To our knowledge, only few econometric models with (a short history of) aggregated data have been accomplished yet in our research field (e.g. Ensslen, Ringler, Jochem, \& Fichtner, 2014; Jeon, 2010; McManus \& Senter, 2009; Plötz, 2011) (cf. Table 5). McManus \& Senter (2009) might be highlighted as a convincing application.

Table 5: Selected literature on econometric models with aggregated data from adoption 


\begin{tabular}{|c|c|c|c|c|}
\hline Authors & Jurisdiction & $\begin{array}{l}\text { Time } \\
\text { horizon }\end{array}$ & Technology & Key features \\
\hline $\begin{array}{l}\text { Dargay et al., } \\
2007\end{array}$ & 45 countries & $\begin{array}{l}2002- \\
2030\end{array}$ & $\begin{array}{l}\text { Overall } \\
\text { vehicle stock }\end{array}$ & $\begin{array}{l}\text { Gompertz model estimation based on pooled time series and cross- } \\
\text { section data. Projections show that vehicle ownership will increase } \\
\text { from } 800 \text { million in } 2002 \text { to over } 2 \text { billion in } 2030 \text {. }\end{array}$ \\
\hline $\begin{array}{l}\text { Romilly, Song, } \\
\text { \& Liu, } 1998\end{array}$ & $\begin{array}{l}\text { Britain } \\
\text { (England, } \\
\text { Scotland and } \\
\text { Wales) }\end{array}$ & $\begin{array}{l}1990- \\
2025\end{array}$ & $\begin{array}{l}\text { Overall } \\
\text { vehicle stock }\end{array}$ & $\begin{array}{l}\text { Model estimation based on time series data from 1953-1994 initially } \\
\text { including seven exogenous determinants of car ownership. Long-range } \\
\text { forecasts are comparably low ( } 416 \text { vehicles per } 1000 \text { citizens in 2025). }\end{array}$ \\
\hline $\begin{array}{l}\text { Ensslen et al., } \\
2014\end{array}$ & Germany & 2030 & EV & $\begin{array}{l}\text { The Bass diffusion scenario estimation is based on EV stock data from } \\
2009 \text { until } 2013 \text { and the assumption that there will be } 5 \text { million EV on } \\
\text { German roads by } 2030 \text {. }\end{array}$ \\
\hline Jeon, 2010 & US & $\begin{array}{l}2009- \\
2030\end{array}$ & $\mathrm{HEV}$ & $\begin{array}{l}\text { The Norton-Bass model estimation is based on time series data of first } \\
\text { generation Toyota Prius from } 2001-2008 \text {. Sales forecasts for four } \\
\text { generations of HEV are projected Fourth generation HEV sales reach } \\
\text { about } 5 \text { million in } 2030 \text {. }\end{array}$ \\
\hline $\begin{array}{l}\text { McManus and } \\
\text { Senter, } 2009\end{array}$ & US & $\begin{array}{l}2010- \\
2050\end{array}$ & PHEV & $\begin{array}{l}\text { Six different PHEV market diffusion models are applied: Bass, } \\
\text { Generalized Bass, Logistic, Gompertz, Centrone additionally using } \\
\text { demographic factors, and a rather complex dynamic system model } \\
\text { accounting for consumer criteria and factors related to consumer } \\
\text { choice. }\end{array}$ \\
\hline Plötz, 2011 & $\begin{array}{l}\text { Germany and } \\
\text { US }\end{array}$ & $\begin{array}{l}2010- \\
2045\end{array}$ & $\begin{array}{l}\text { HEV, PHEV, } \\
\text { BEV, ICEV }\end{array}$ & $\begin{array}{l}\text { The Lotka-Volterra model is applied. The results focus on the } \\
\text { competition between EV and HEV. }\end{array}$ \\
\hline
\end{tabular}

\section{Discussion}

Given our purpose and the initial market conditions at the present time, aggregate methods represent a rather unsuitable approach to this task in the current market phase with only limited historical data series available (cf. Table 6). Instead, disaggregate econometric models analyzing discrete choices might be preferred. However, as observed data becomes increasingly available, the aggregate econometrics method is expected to become increasingly useful for gaining insights into the prospects of vehicle technology market development. For short-term forecasting using monthly data, the Box-Jenkins approach may already deliver accurate forecasts. 
Table 6: Advantages and disadvantages of econometric models with aggregated data

\begin{tabular}{|l|l|}
\hline ADVANTAGES & DISADVANTAGES \\
\hline $\begin{array}{l}\text { Desirable combination of theory and } \\
\text { empirical basis. }\end{array}$ & $\begin{array}{l}\text { The method relies on the availability of } \\
\text { extensive high quality data (the lack of }\end{array}$ \\
$\begin{array}{l}\text { The method may be used to precisely } \\
\text { quantify new (economic) relationships. } \\
\text { The method emphasizes testing and } \\
\text { facilitates the testing of hypotheses. }\end{array}$ & $\begin{array}{l}\text { overreliance on stated preference data and } \\
\text { disaggregated econometric modeling) }\end{array}$ \\
& $\begin{array}{l}\text { Its strength is rather in short time horizons } \\
\text { (which is less relevant in the context of the } \\
\text { deployment of new vehicle technology). }\end{array}$ \\
& $\begin{array}{l}\text { Regional specialties are hard to consider due } \\
\text { to lack of data. } \\
\text { There is a risk for model misspecification } \\
\text { and inadequate statistical inferences. }\end{array}$ \\
\hline
\end{tabular}

\subsection{System Dynamics Models}

System dynamic (SD) represents an alternative approach to modelling car technologies uptake.

\section{History}

SD started to be developed by Jay W. Forrester in 1956 (Forrester, 1995), five years

before his seminal work Industrial Dynamics (Forrester, 1961) was published. Although initially conceived for solving corporate problems, SD proved to be successful in its application to other social and environmental problems, regardless of whether the focus was local or global. This was reflected in works such as Urban Dynamics (Forrester, 1969) and World Dynamics, which introduced the SD model known as WORLD1 (Forrester, 1973). The global modeling exercise reported in The Limits to Growth (Meadows, 1972) perhaps remains the most famous application of the SD approach to date. Because of its emphasis on the endogenous point of view and feedback processes (Richardson, 2011), SD is regarded as a useful approach to understand complex dynamic systems.

\section{Main characteristics and assumptions}

Mathematically, SD models are sets of ordinary differential equations which can be 
computationally solved as approximations by numerical integration methods such as Euler or Runge-Kutta. For applications in the research field of market penetration of $\mathrm{EV}$, the following five features of SD models can be highlighted. (1) Dynamic modeling, the explicit consideration of the independent variable 'time' is crucial in SD models. Investigation of the future market penetration of new technologies, preferably on a yearly basis, necessarily requires this approach. (2) Explanatory model for simulating behavior, is a key aspect in SD models (Bossel, 2007). SD modeling entails computer simulation, by which 'what-if' questions can be answered as if it were a controlled experiment. (3) Feedback process, where an input variable affects the output, but this also impacts (feeds back) the input after a time lag. From a consumer perspective, it is expected that important feedback loops affect the buying behavior of potential adopters, e.g. when they get more acquainted (through time) with new technologies by having the chance to use them or through peer effects. The explicit incorporation of feedback processes is at the core of SD modeling. (4) Long model time horizons, usually longer than 20 years are considered. An underlying premise is that, for most systems, the patterns of behavior can be fully visualized only when the appropriate (long-term) horizon is considered. (5) Delays, i.e. the existence of significant time lags between variables - similar to econometrics - is assumed. The data requirement depends on the research question.

\section{Literature}

$\mathrm{SD}$ is versatile as it enables the integration with other approaches. We identify three common mixed modeling approaches within the SD framework. Firstly, the embedment of discrete choice frameworks (cf. Section 3.1) within SD models for reflecting choice behavior is often applied. In this framework, individuals do not interact; thus a diffusion framework is often included as complementary, in an attempt to capture interactions. 
Secondly, Bass diffusion frameworks (cf. Section 4.1) are incorporated for simulating the diffusion of different vehicle drivetrains (e.g. Sterman, 2000). This example contains two stock variables (Potential Adopters and Adopters), connected by a single flow variable (Adoption Rate), and illustrates three feedback loops: Two of them are negative feedbacks reflecting 'market saturation' and the third is positive, reflecting the effect of 'word of mouth'. Thirdly, hybrid models, e.g. combining SD and ABM, have been developed. From the perspective of the automobile industry, a combination of market chances $(\mathrm{SD})$ and concrete purchases $(\mathrm{ABM})$ indicates an attractive modeling approach (see Weikl, 2010; Wansart, 2012; Jensen et al., 2016; Kieckhäfer et al., 2014). Table 7 provides an overview of SD studies for the purpose of investigating the market penetration of alternative LDV technologies. Ford (1995) provides an influential paper in our research field.

Table 7: Overview of selected SD literature on market penetration of electric vehicles 


\begin{tabular}{|c|c|c|c|c|}
\hline Authors & Jurisdiction & $\begin{array}{l}\text { Time } \\
\text { horizon }\end{array}$ & Technology & Key features \\
\hline $\begin{array}{l}\text { Ford, 1995; } \\
\text { Ford, 1999; } \\
\text { BenDor and } \\
\text { Ford, } 2006\end{array}$ & $\begin{array}{l}\text { US } \\
\text { (California) }\end{array}$ & 20 years & $\begin{array}{l}\text { CNG, HEV, } \\
\text { EV }\end{array}$ & $\begin{array}{l}\text { Drawing from the results of (Bunch et al., 1993), an SD model for } \\
\text { analyzing a feebate scheme was built. The purchase decision is based } \\
\text { on a multinomial logit (MNL) framework that includes six main } \\
\text { attributes. }\end{array}$ \\
\hline $\begin{array}{l}\text { Schade, 2005; } \\
\text { Krail, 2009; } \\
\text { Fiorello et al., } \\
2010\end{array}$ & $\begin{array}{l}\text { EU27, } \\
\text { Switzerland, } \\
\text { Norway }\end{array}$ & 2050 & $\begin{array}{l}\text { HEV, CNG, } \\
\text { LPG, FFV, } \\
\text { BEV, FCEV }\end{array}$ & $\begin{array}{l}\text { ASTRA (ASsessment of TRAnsport Strategies)'s vehicle fleet module } \\
\text { is affected by population change and disposable income. } \\
\text { The vehicle fleet models (VFT module) include a discrete choice } \\
\text { component. The development of technologies and ageing of vehicles is } \\
\text { considered. There are several feedbacks between and within the } \\
\text { modules. }\end{array}$ \\
\hline Purwanto, 2013 & $\begin{array}{l}57 \text { world } \\
\text { regions }\end{array}$ & 2050 & $\begin{array}{l}\text { HEV, CNG, } \\
\text { LPG, BEV, } \\
\text { FCEV }\end{array}$ & $\begin{array}{l}\text { The MOVEET (MObility, Vehicle fleet, Energy use and Emissions } \\
\text { forecast Tool) [former GLADYSTE, based on TREMOVE] model } \\
\text { consists of four interrelated modules: "Transport Demand", } \\
\text { "Environmental", "Welfare", and "Fleet". The latter contains a vehicle } \\
\text { structure by type and technology. A nested logit computes mode } \\
\text { shares. The shares of vehicles sold depend on GDP, acceleration time, } \\
\text { fuel and non-fuel costs, and other parameters. }\end{array}$ \\
\hline $\begin{array}{l}\text { Struben and } \\
\text { Sterman, } 2008\end{array}$ & $\begin{array}{l}\text { US } \\
\text { (California) }\end{array}$ & 60 years & $\begin{array}{l}\text { HEV, CNG, } \\
\text { Biofuels, } \\
\text { FCEV }\end{array}$ & $\begin{array}{l}\text { The model considers feedback from consumers' experience as well as } \\
\text { word-of-mouth, marketing and network effects focusing on alternative } \\
\text { drive trains. A simulation of learning, technological spillovers, and } \\
\text { spatial coevolution of fueling infrastructure adds additional feedbacks } \\
\text { that condition the diffusion process. The choice modeling is based on a } \\
\text { standard multinomial logit (MNL) framework. }\end{array}$ \\
\hline Meyer, 2009 & $\begin{array}{l}\text { Germany, } \\
\text { Japan }\end{array}$ & 2035 & $\begin{array}{l}\mathrm{HEV}, \mathrm{CNG}, \\
\mathrm{BEV}, \mathrm{FCEV}\end{array}$ & $\begin{array}{l}\text { Partially building on previous work by (Ford, 1999), the author deals } \\
\text { with the German and Japanese markets. Vehicle aging chains are used } \\
\text { and ten different utility coefficients are considered. In addition, other } \\
\text { exogenous factors affect the market share by type of vehicle. }\end{array}$ \\
\hline $\begin{array}{l}\text { Walther et al., } \\
2010\end{array}$ & $\begin{array}{l}\text { US } \\
\text { (California) }\end{array}$ & 2021 & ZEV & $\begin{array}{l}\text { The authors consider four interacting modules: "GHG and ZEV } \\
\text { regulations", "Automotive industry", "Customers", and "Vehicle stock } \\
\text { and infrastructure". Consumer awareness affects the choice of } \\
\text { powertrain. This is based on an extended Bass model that represents } \\
\text { the processes of 'word-of-mouth', 'oblivion' and marketing efforts. This } \\
\text { influences consumers' choice set which, together with the assumed } \\
\text { preferences, determine the market share of powertrains and segments. }\end{array}$ \\
\hline
\end{tabular}




\begin{tabular}{|c|c|c|c|c|}
\hline Keith, 2012 & US & 2050 & $\begin{array}{l}\text { CNG, HEV, } \\
\text { PHEV, BEV }\end{array}$ & $\begin{array}{l}\text { A nested multinomial logit (NMNL) model is applied to describe the } \\
\text { decision-making process. Vehicle choice results from the utility that } \\
\text { the consumer derives for each platform, as a function of purchase } \\
\text { price, operating cost, emissions and range. In addition, the concept of } \\
\text { familiarity with different platforms is employed. }\end{array}$ \\
\hline $\begin{array}{l}\text { Shepherd et al., } \\
2012\end{array}$ & UK & 2050 & PHEV, BEV & $\begin{array}{l}\text { Building upon the work by (Struben \& Sterman, 2008), (Shepherd et } \\
\text { al., 2012) modeled EV uptake using choice values estimated by } \\
\text { (Batley, Toner, \& Knight, 2004). The main factors considered were } \\
\text { purchase price, operating costs, maximum speed, fuel availability, } \\
\text { emissions, and range. }\end{array}$ \\
\hline $\begin{array}{l}\text { Pasaoglu et al., } \\
2016\end{array}$ & EU28 & 2050 & $\begin{array}{l}\text { LPG, CNG, } \\
\text { Biofuels, } \\
\text { HEV, PHEV, } \\
\text { BEV, FCEV }\end{array}$ & $\begin{array}{l}\text { The model consists of representative market agents. The following } \\
\text { utility criteria are used to model the purchasing decision on the type of } \\
\text { powertrain: Environment, performance, reliability, safety, } \\
\text { convenience, popularity, choice, and cost. Using the idea of } \\
\text { 'willingness to consider' (WtC) a given powertrain, based on Struben } \\
\text { and Sterman (2008), a user's 'consideration set' is derived. }\end{array}$ \\
\hline
\end{tabular}

\section{Discussion}

SD represents a suitable method to investigate system-wide effects. This appears to be a desirable feature when modeling the uptake of electric vehicles, which takes place within a complex socio-technical system. By its nature, the method simulates relationships at a rather highly aggregated level. However, examples exist of work that combines this system-wide aggregate approach with the disaggregate method. This is currently a fruitful line of research in the context of car technology market penetration (cf. Table 8).

Table 8: Advantages and disadvantages of system dynamics models

\begin{tabular}{|c|c|}
\hline ADVANTAGES & DISADVANTAGES \\
\hline $\begin{array}{l}\text { Disequilibrium processes can be modeled } \\
\text { explicitly. } \\
\text { - The method supports nonlinear simulation } \\
\text { over long time horizons. } \\
\text { - There exist several standardized toolboxes } \\
\text { for implementing SD approaches. } \\
\text { There were considerable improvements with } \\
\text { regard to transparency; e.g. dimensional } \\
\text { consistency checks and a high level of }\end{array}$ & $\begin{array}{l}\text { Method's pragmatic approach to analysis of } \\
\text { historical data (usually without econometric } \\
\text { methods) mixed with other assumptions } \\
\text { makes the method subject to criticism. } \\
\text { - Due to a weak theoretical background it is } \\
\text { hard to follow all assumptions. }\end{array}$ \\
\hline
\end{tabular}


transparency, reproducibility and

communication (Martinez-Moyano, 2012),

(Rahmandad \& Sterman, 2012).

\subsection{Integrated Assessment and General Equilibrium Models}

Integrated assessment models (IAMs) are widely applied in interdisciplinary environmental sciences for global projections in the field of energy and climate change (e.g. (IPCC (Intergovernmental Panel on Climate Change), 2014). The macroeconomic part of these models might be based on general equilibrium models, which are based on economic theory. They use aggregated economic data and are usually focused on the impact analysis of policy instruments, changes in technology or other external factors. Therefore, only this part of integrated assessment models is of interest here. Today, most general equilibrium models also include microeconomic data and are therefore seen as bottom-up models or hybrid models (Böhringer \& Rutherford, 2008). Nevertheless, we keep them in our top-down classification.

\section{History}

The concept of economic equilibrium lies at the heart of general equilibrium models. Not before the 1960s, when computational analysis became common for all research disciplines, economic equilibrium models developed from pure mathematical calculations with few empirical-based data to empirical-data based models. This was the hour of birth of computable general equilibrium (CGE) models (e.g. Harberger, 1962), which are widely used today in applied macroeconomics (Shoven \& Whalley, 1984). More recent developments are Spatial or Dynamic Stochastic General Equilibrium Models (DSGE). Recently, DSGE models have been subject to not insubstantial criticism (cf. Caiani et al., 2016). Integrated assessment models have a long history in environmental sciences and are currently under comprehensive development. For 
vehicle choice modeling, they are being extended by many behavioral features (cf. McCollum et al., 2016).

\section{Main characteristics and assumptions}

CGE models are mainly based on data from the system of national accounts or the input-output matrix (Miller \& Blair, 2009) and can have microeconomic foundations such as technical production limitations (Böhringer, Löschel, \& Rutherford, 2004). In this way, the models optimize at the macroeconomic level and assume utilitymaximizing and representative individuals, complete markets without external effects and public goods, complete information, perfect competition, etc. CGE models often examine macroeconomic issues, which today typically have an empirical background (Böhringer et al., 2004). By limiting the market outcome to economic equilibrium, their results are limited from an empirical perspective - particularly in non-Walrasian market situations. However, recent CGE models allow deviation from the equilibrium (e.g. Sampson, 2013). Calibrating the model is still a challenge and is mainly based on values from the literature or estimated by econometric approaches and confirmed by a sensitivity analysis (Boulanger \& Bréchet, 2002). If correctly calibrated, CGE models are especially suited to determining long-term forecasts.

\section{Literature}

In the context of market penetration of electric vehicles, only few CGE-based studies exist. Most models apply the rather theoretical constant elasticity-of-substitution (CES) approach to all drivetrain technologies (e.g. Karplus, Paltsev, \& Reilly, 2010), whereas also other methodologies are applied, e.g. a hard-linked MNL (cf. Table 9). A comprehensive overview of IAM for vehicle choice can be found in McCollum et al. (2016). 
Table 9: Overview of literature on market penetration of electric vehicles based on general equilibrium models

\begin{tabular}{|c|c|c|c|c|}
\hline Authors & Jurisdiction & $\begin{array}{l}\text { Time } \\
\text { horizon }\end{array}$ & Technology & Key features \\
\hline $\begin{array}{l}\text { Schäfer and } \\
\text { Jacoby, } 2006\end{array}$ & US & 2030 & $\begin{array}{l}\text { Different } \\
\text { technological } \\
\text { improvements }\end{array}$ & $\begin{array}{l}\text { The MARKAL model is linked to the EPPA (emission production } \\
\text { and policy analysis) model in order to consider also influences from } \\
\text { the economy. Eight technology improvements for conventional cars } \\
\text { are considered, including hybridization. }\end{array}$ \\
\hline $\begin{array}{l}\text { Schmelzer and } \\
\text { Miess, } 2015\end{array}$ & Austria & 2030 & EV, PHEV & $\begin{array}{l}\text { A hard-linked MNL model is used for the technology choice of } \\
\text { households instead of the usual constant-elasticity-of-substitution } \\
\text { (CES) approach. The authors even consider spatial differences. }\end{array}$ \\
\hline $\begin{array}{l}\text { Karplus et al., } \\
2010\end{array}$ & US and Japan & 2100 & Biofuels, PHEV & $\begin{array}{l}\text { The alternative technology PHEV is considered as a perfect } \\
\text { substitute of conventional vehicles in the EPPA model. Biofuels are } \\
\text { also considered as an alternative to electrification. The choice } \\
\text { between the perfect substitutes is based on a usual constant- } \\
\text { elasticity-of-substitution (CES) approach. }\end{array}$ \\
\hline Yeh et al., 2008 & US & 2050 & PHEV & $\begin{array}{l}\text { A MARKAL model based on Shay et al. (2006) is applied, and the } \\
\text { technology decision remains unclear. }\end{array}$ \\
\hline
\end{tabular}

\section{Discussion}

General equilibrium models have a strong theoretical basis from economic theory and lead to unique results - especially for long-term scenarios. This comes, however, along with some drawbacks such as that the (mostly) simplifying assumptions of user behavior might not represent reality of car purchase decisions and disruptive innovations are hard to capture (cf. Table 10).

Table 10: Advantages and disadvantages of integrated assessment and general equilibrium models

\begin{tabular}{|c|c|}
\hline ADVANTAGES & DISADVANTAGES \\
\hline $\begin{array}{l}\text { - CGE: Strong theoretical basis. } \\
\text { - CGE: Comprehensive structural view of the } \\
\text { economy. } \\
\text { - IAM/CGE: Consistent scenarios of long time } \\
\text { horizons possible. } \\
\text { - CGE: Unique solution. }\end{array}$ & $\begin{array}{l}\text { - IAM: Weak theoretical basis. } \\
\text { - CGE: Rational expectations assumption } \\
\text { arguably unrealistic. } \\
\text { - IAM: Due to a weak theoretical background } \\
\text { it is hard to follow all assumptions. } \\
\text { - CGE: Simplifying assumptions required to } \\
\text { make the model tractable. } \\
\text { - CGE: Nonlinearities are hard to capture. }\end{array}$ \\
\hline
\end{tabular}




\section{$5 \quad$ Hybrid Models}

Hybrid models (i.e. models, which use bottom-up and top-down approaches) are more and more recommended in academia for analyzing the market share of alternative drivetrains in order to consider both, the individual decision, as well as the overriding trend in society and the vehicle supply (Brand, Anable, \& Tran, 2013; Brand, Tran, \& Anable, 2012; Jensen et al., 2016; Kieckhäfer et al., 2014; Wansart, 2012; Weikl, 2010). Furthermore, these hybrid models are already broadly applied in comprehensive longterm global models developed by policy consultants: E.g., the data spread sheet models Mobility Model (MoMo by the International Energy Agency (IEA)) (Fulton, Cazzola, \& Cuenot, 2009) and the Roadmap Model (by the International Council on Clean Transportation (ICCT)) as well as the system dynamic-based ForFITS model (by United Nation Economic Commission for Europe). In addition, in European policy consulting, several hybrid models are developed such as ASTRA, POLES, TRANS-TOOLS (TOOLS for TRansport Forecasting ANd Scenario testing) and TREMOVE.

In academia, these hybrid approaches are, however, still underrepresented even though new convincing developments are proposed e.g., by Zhang and Vorobeychik (2016), who suggested to integrate more machine learning algorithms, which consider both macrolevel and micro-level such as cross-validation, or validate the models with independent data, which is not used for model calibration. Application of these methods is based on the availability of comprehensive data sets. The current tremendous increase in data volumes from transportation will contribute to an improvement of these models. Future data is not only based on mobility data, but also comes from other sources such as social media (Rand, Herrmann, Schein, \& Vodopivec, 2015). This might lead to a more datadriven approach in our field of investigation. 


\section{Discussion}

There is a high variety of methods applied in the literature for forecasting the market penetration of electric drivetrains in the passenger car market. There is no dominating methodology, but it seems that each method has its advantage in certain fields.

Nevertheless, we indicate the strength and weakness of each method according to four main dimensions (1) main basis (theoretically vs. empirically), (2) transparency and (3) flexibility of modelling as well as (4) appropriate time horizon (short-term vs. longterm) in Figure 3.

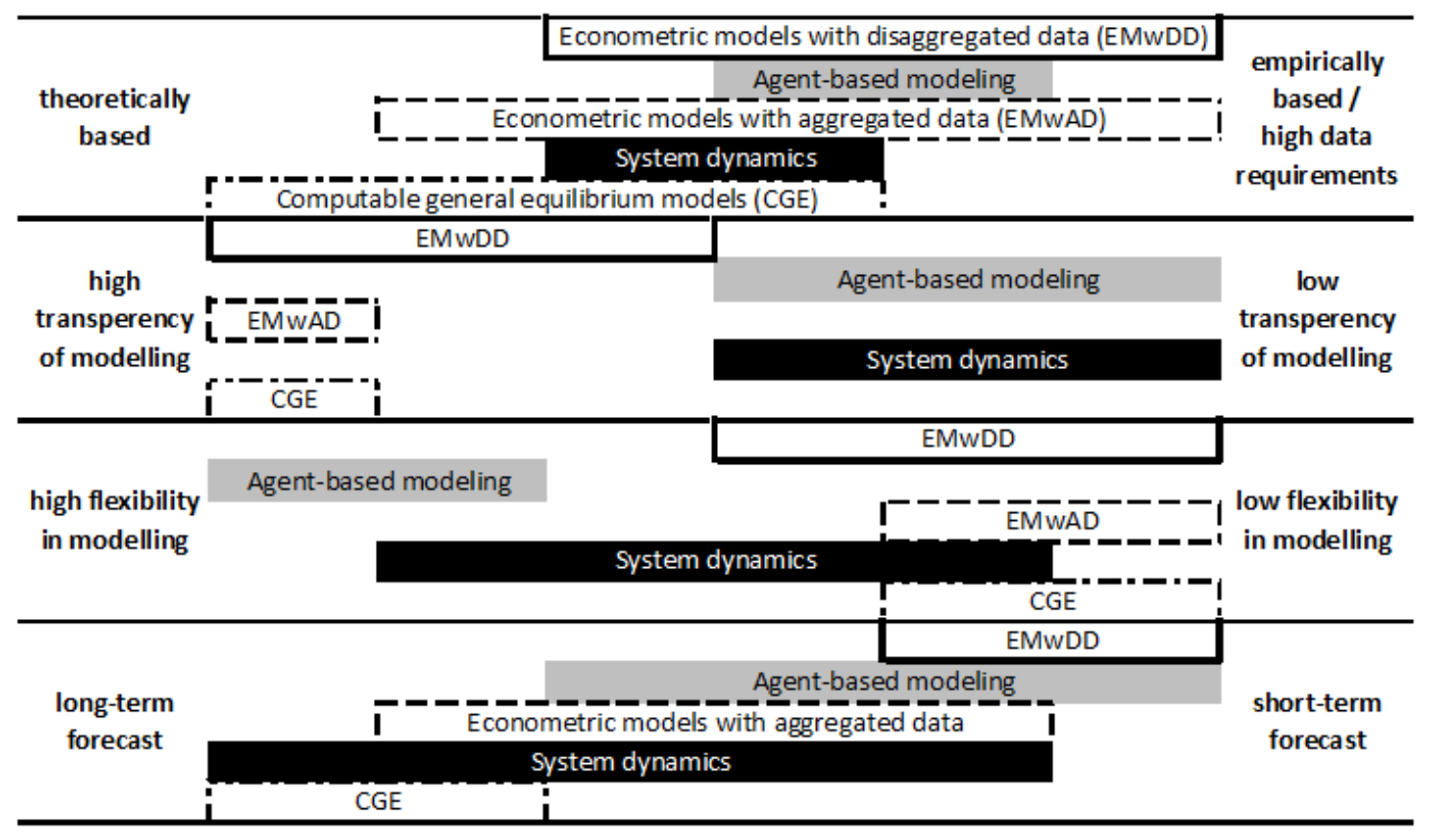

Figure 3: Evaluation of modeling approaches according to four dimensions

The theoretical basis seems to be strong for both CGE and econometric approaches, which convince for stable market conditions. However, the strong theoretical basis makes some methodological applications more unrealistic (e.g. theoretical CGE models). A weak theoretical basis leads on the one hand to less transparency of modeling which comes along with a limited reproducibility and on the other hand to a high degree of freedom for model developers. Hence, econometric modeling convinces strongly with a profound theoretical basis without neglecting 
empirical soundness and high transparency of modeling, but requires a comprehensive database.

Another main dimension, where applied methodologies perform differently is the flexibility of modeling, where ABM and SD perform best. However a high flexibility is often correlated with a low transparency in modeling. Finally, pure econometric approaches are rather focused on short- to mid-term forecasts. For longterm forecasts, CGE and SD models perform best.

A combination of pure modeling techniques such as CGE, SD or AGM with econometric methods seems to be a promising combination of measuring the empirical historical development, using expert insights about the future and using the existing theoretical basis of modeling.

For early market phases, especially disaggregated econometric bottom-up models seem to be appropriate to generate an adequate basis for market prognoses. However, these econometric models are highly relying on comprehensive data which comes along with high costs of data collection. While data collected from user acceptance studies can be used for past or present decisions, the stated preferences on future decisions should be handled more carefully.

If disaggregated data is available and a concrete car purchase decision is in the core of the specific research question (mainly perspective of the car industry) and the focus is on the short- to mid-term development, $\mathrm{ABM}$ and econometric based models with disaggregated data seem favorable. For long-term forecasts (mainly perspective of politics), macroeconomic based models, mainly CGE and SD, seem to be more appropriate. Due to the relatively new market development of this technology, a pure application of econometric models with aggregated data cannot convince in our research area. 
Finally, the market penetration of electric drivetrains depends on the car purchase decision of the main three customer sub-groups, i.e. (1) companies buying fleet vehicles for their fleets, (2) companies buying company cars for their employees, and (3) private persons buying cars for themselves or other family members. All three customer groups react differently and even within a group significant differences might be observed (de Haan et al., 2009; Gnann et al., 2015; Ketelaer, Kaschub, Jochem, \& Fichtner, 2014). However, all decision makers consider (at least implicitly) the following decision factors:

- Personal beliefs and attitudes (micro-level), such as innovativeness, environmental attitudes, preferences for different makes, vehicle types, etc., which can be influenced by macro-level factors such as media or politics,

- budget and phase of life (micro-level), all decision makers usually have budget restrictions, and private customers take their current phases of life into consideration (e.g. retirement, etc.),

- mobility patterns (micro-level), refer mainly to annual mileage, but also to daily patterns, which might be restricted by the range of some cars,

- external factors (macro-level), such as political influences (i.e. incentives), fuel prices, availability of fueling stations, etc.,

- other factors (mainly macro-level), which include all other influences.

Concluding, future models should consider the macro- and micro-levels by all five decision factors differentiated by the three sub-groups, fleet vehicles, company cars, and private cars. For this, a comprehensive collection of economic, market and social data is necessary. 
As there has been no market penetration of a similar technology and the current market uptake of electric vehicles is still at a very early stage, it will take time to fully validate the model results. Nevertheless, methods from other markets and the increasing volume of mobility data provide promising improvements in our research field.

\section{Conclusion}

In this paper, we analyze different methods for forecasting the market penetration of electric drivetrains in the passenger car market in order to structure them and highlight their strengths and weaknesses. We classify the methods into bottom-up and top-down models. For the former, we identify microeconometric models and agent-based simulation models, which focus on representing the user decision. Econometric models with aggregated data, system dynamics, and integrated assessment models with general equilibrium models are classified in the top-down models. As a trend in the literature already indicates, hybrid approaches, considering micro and macro aspects seem to be most appropriate for analyzing the market penetration of electric drivetrains in the passenger car market. This is a consequential conclusion from the finding that not only personal beliefs (bottom-up effect) influence our car purchase decision, but also other social, economic and political factors (top-down effect). Furthermore, the differentiation between the three sub-groups, fleet vehicles, company cars, and private cars combined with suitable methods should be included in future models. The current increase in data volumes from transportation will contribute to this development.

The literature in this research field has been gaining momentum in the last years. Therefore, we may be far from giving a complete overview of the research field. Our argumentation is focused on our research question and may seem inappropriate for other fields of application. 


\section{References}

Abou-Zeid, M., \& Ben-Akiva, M. (2014). Hybrid Choice Models. In S. Hess \& A. Daly, Handbook of choice modelling. Edward Elgar Publishing.

Achtnicht, M., Bühler, G., \& Hermeling, C. (2012). The impact of fuel availability on demand for alternative-fuel vehicles. Transportation Research Part D: Transport and Environment, 17(3), 262-269. https://doi.org/10.1016/j.trd.2011.12.005

Al-Alawi, B. M., \& Bradley, T. H. (2013). Review of hybrid, plug-in hybrid, and electric vehicle market modeling Studies. Renewable and Sustainable Energy Reviews, 21, 190-203. https://doi.org/10.1016/j.rser.2012.12.048

Anowar, S., Eluru, N., \& Miranda-Moreno, L. F. (2014). Alternative Modeling Approaches Used for Examining Automobile Ownership: A Comprehensive Review. Transport Reviews, 34(4), 441-473. https://doi.org/10.1080/01441647.2014.915440

Axsen, J., TyreeHageman, J., \& Lentz, A. (2012). Lifestyle practices and proenvironmental technology. Ecological Economics, 82, 64-74. https://doi.org/10.1016/j.ecolecon.2012.07.013

Bass, F. M. (1969). A New Product Growth for Model Consumer Durables. Management Science, 15(5), 215-227. https://doi.org/10.1287/mnsc.15.5.215

Bass, F. M. (2004). Comments on “A New Product Growth for Model Consumer Durables The Bass Model.” Management Science, 50(12_supplement), 18331840. https://doi.org/10.1287/mnsc. 1040.0300

Batley, R. P., Toner, J. P., \& Knight, M. J. (2004). A mixed logit model of U.K. household demand for alternative-fuel vehicles. International Journal of Transport Economics / Rivista Internazionale Di Economia Dei Trasporti, 31(1), 55-77. 
Ben-Akiva, M., McFadden, D., Gärling, T., Gopinath, D., Walker, J., Bolduc, D., ... Rao, V. (1999). Extended Framework for Modeling Choice Behavior. Marketing Letters, 10(3), 187-203. https://doi.org/10.1023/A:1008046730291

Ben-Akiva, M., Mcfadden, D., Train, K., Walker, J., Bhat, C., Bierlaire, M., ... Munizaga, M. A. (2002). Hybrid Choice Models: Progress and Challenges. Marketing Letters, 13(3), 163-175. https://doi.org/10.1023/A:1020254301302

Ben-Akiva, M., McFadden, D., Train, K., Walker, J., Bhat, C., Bierlaire, M., ... Munizga, M. (2002). Hybid Choice Models: Progress and Challenges. Marketing Letters 13, 163 - 175., 13, 163 - 175.

BenDor, T., \& Ford, A. (2006). Simulating a combination of feebates and scrappage incentives to reduce automobile emissions. Energy, 31(8-9), 1197-1214. https://doi.org/10.1016/j.energy.2005.05.024

Bhat, C. R., \& Dubey, S. K. (2014). A new estimation approach to integrate latent psychological constructs in choice modeling. Transportation Research Part B: Methodological, 67, 68-85. https://doi.org/10.1016/j.trb.2014.04.011

Böhringer, C., Löschel, A., \& Rutherford, T. F. (2004). Efficiency Gains from "What" Flexibility in Climate Policy - an Integrated Cge Assessment. SSRN Electronic Journal. https://doi.org/10.2139/ssrn.606401

Böhringer, C., \& Rutherford, T. F. (2008). Combining bottom-up and top-down. Energy Economics, 30(2), 574-596. https://doi.org/10.1016/j.eneco.2007.03.004

Bossel, H. (2007). Systems and Models: Complexity, Dynamics, Evolution, Sustainability. Norderstedt: Books on Demand.

Boulanger, P.-M., \& Bréchet, T. (2002). Setting concepts into motion: improving scientific tools in support of sustainable development decision-making. 
Box, G. E. P., \& Jenkins, G. M. (1976). Time Series Analysis: Forecasting and Control (4 edition). Hoboken, N.J: Wiley.

Boyd, J. H., \& Mellman, R. E. (1980). The effect of fuel economy standards on the U.S. automotive market: An hedonic demand analysis. Transportation Research Part A: General, 14(5-6), 367-378. https://doi.org/10.1016/0191-2607(80)90055-2

Brand, C., Anable, J., \& Tran, M. (2013). Accelerating the transformation to a low carbon passenger transport system: The role of car purchase taxes, feebates, road taxes and scrappage incentives in the UK. Transportation Research Part A: Policy and Practice, 49, 132-148. https://doi.org/10.1016/j.tra.2013.01.010

Brand, C., Cluzel, C., \& Anable, J. (2017). Modeling the uptake of plug-in vehicles in a heterogeneous car market using a consumer segmentation approach.

Transportation Research Part A: Policy and Practice, 97, 121-136. https://doi.org/10.1016/j.tra.2017.01.017

Brand, C., Tran, M., \& Anable, J. (2012). The UK transport carbon model: An integrated life cycle approach to explore low carbon futures. Energy Policy, 41, 107-124. https://doi.org/10.1016/j.enpol.2010.08.019

Brown, M. (2013). Catching the PHEVer: Simulating Electric Vehicle Diffusion with an Agent-Based Mixed Logit Model of Vehicle Choice. JASSS, 16(2). https://doi.org/10.18564/jasss.2127

Brownstone, D., Bunch, D. S., \& Train, K. (2000). Joint mixed logit models of stated and revealed preferences for alternative-fuel vehicles. Transportation Research Part B: Methodological, 34(5), 315-338. https://doi.org/10.1016/s01912615(99)00031-4 
Brownstone, D., \& Train, K. (1998). Forecasting new product penetration with flexible substitution patterns. Journal of Econometrics, 89(1-2), 109-129. https://doi.org/10.1016/S0304-4076(98)00057-8

Bunch, D. S., Bradley, M., Golob, T. F., Kitamura, R., \& Occhiuzzo, G. P. (1993). Demand for clean-fuel vehicles in California: A discrete-choice stated preference pilot project. Transportation Research Part A: Policy and Practice, 27(3), 237-253. https://doi.org/10.1016/0965-8564(93)90062-P

Burgess, M., King, N., Harris, M., \& Lewis, E. (2013). Electric vehicle drivers' reported interactions with the public: Driving stereotype change? Transportation Research Part F: Traffic Psychology and Behaviour, 17, 33-44. https://doi.org/10.1016/j.trf.2012.09.003

Caiani, A., Godin, A., Caverzasi, E., Gallegati, M., Kinsella, S., \& Stiglitz, J. E. (2016). Agent based-stock flow consistent macroeconomics: Towards a benchmark model. Journal of Economic Dynamics and Control, 69, 375-408. https://doi.org/10.1016/j.jedc.2016.06.001

Caperello, N. D., \& Kurani, K. S. (2012). Households' Stories of Their Encounters With a Plug-In Hybrid Electric Vehicle. Environment and Behavior, 44(4), 493-508. https://doi.org/10.1177/0013916511402057

Carley, S., Krause, R. M., Lane, B. W., \& Graham, J. D. (2013). Intent to purchase a plug-in electric vehicle: A survey of early impressions in large US cites. Transportation Research Part D: Transport and Environment, 18, 39-45. https://doi.org/10.1016/j.trd.2012.09.007

Chorus, C. G., Arentze, T. A., \& Timmermans, H. J. P. (2008). A Random RegretMinimization model of travel choice. Transportation Research Part B: Methodological, 42(1), 1-18. https://doi.org/10.1016/j.trb.2007.05.004 
Coffman, M., Bernstein, P., \& Wee, S. (2015). Factors Affecting EV Adoption: A Literature Review and EV Forecast for Hawaii.

Creutzig, F., Jochem, P., Edelenbosch, O. Y., Mattauch, L., Vuuren, D. P. v., McCollum, D., \& Minx, J. (2015). Transport: A roadblock to climate change mitigation? Science, 350(6263), 911-912. https://doi.org/10.1126/science.aac8033

Cui, X., Liu, C., Kim, H. K., Kao, S.-C., Tuttle, M. A., \& Bhaduri, B. L. (2010). A multi agent-based framework for simulating household PHEV distribution and electric distribution network impact.

Dagsvik, J. K., Wennemo, T., Wetterwald, D. G., \& Aaberge, R. (2002). Potential demand for alternative fuel vehicles. Transportation Research Part B: Methodological, 36(4), 361-384. https://doi.org/10.1016/S0965-8564(01)000131

Dargay, J., Gately, D., \& Sommer, M. (2007). Vehicle Ownership and Income Growth, Worldwide: 1960-2030. The Energy Journal, 28(4), 143-170.

Daziano, R. A. (2015). Inference on mode preferences, vehicle purchases, and the energy paradox using a Bayesian structural choice model. Transportation Research Part B: Methodological, 76, 1-26.

https://doi.org/10.1016/j.trb.2015.02.012

Daziano, R. A., \& Achtnicht, M. (2014). Forecasting Adoption of Ultra-Low-Emission Vehicles Using Bayes Estimates of a Multinomial Probit Model and the GHK Simulator. Transportation Science, 48(4), 671-683. https://doi.org/10.1287/trsc.2013.0464 
Daziano, R. A., \& Bolduc, D. (2011). Incorporating pro-environmental preferences towards green automobile technologies through a Bayesian hybrid choice model. Transportmetrica, 1-33. https://doi.org/10.1080/18128602.2010.524173

de Haan, P., Mueller, M. G., \& Scholz, R. W. (2009). How much do incentives affect car purchase? Agent-based microsimulation of consumer choice of new carsPart II: Forecasting effects of feebates based on energy-efficiency. Energy Policy, 37(3), 1083-1094. https://doi.org/10.1016/j.enpol.2008.11.003

de Weerdt, M. M., Zhang, Y., \& Klos, T. (2012). Multiagent task allocation in social networks. Autonomous Agents and Multi-Agent Systems, 25(1), 46-86. https://doi.org/10.1007/s10458-011-9168-3

Densing, M., Turton, H., \& Bäuml, G. (2012). Conditions for the successful deployment of electric vehicles - A global energy system perspective. Energy, 47(1), 137149. https://doi.org/10.1016/j.energy.2012.09.011

Egbue, O., \& Long, S. (2012). Barriers to widespread adoption of electric vehicles: An analysis of consumer attitudes and perceptions. Energy Policy, 48, 717-729. https://doi.org/10.1016/j.enpol.2012.06.009

Ensslen, A., Ringler, P., Jochem, P., \& Fichtner, W. (2014). About business model specifications of a smart charging manager to integrate electric vehicles into the German electricity market. In 4th IAEE European Conference. Rome.

Eppstein, M. J., Grover, D. K., Marshall, J. S., \& Rizzo, D. M. (2011). An agent-based model to study market penetration of plug-in hybrid electric vehicles. Energy Policy, 39(6), 3789-3802. https://doi.org/10.1016/j.enpol.2011.04.007

Fiorello, D., Fermi, F., \& Bielanska, D. (2010). The ASTRA model for strategic assessment of transport policies. System Dynamics Review, 26(3), 283-290. https://doi.org/10.1002/sdr.452 
Ford, A. (1995). Simulating the controllability of feebates. System Dynamics Review, 11(1), 3-29. https://doi.org/10.1002/sdr.4260110103

Ford, A. (1999). Modeling the Environment: An Introduction To System Dynamics Modeling Of Environmental Systems (1st ed.). Island Press.

Forrester, J. W. (1961). Industrial Dynamics. Cambridge, Mass.: MIT Press.

Forrester, J. W. (1969). Urban Dynamics. Cambridge, Mass.: MIT Press.

Forrester, J. W. (1973). World Dynamics (Auflage: 2nd Revised edition). Cambridge, Mass: MIT Press.

Forrester, J. W. (1995). Counterintuitive behavior of social systems. Update of the original text appeared in the January, 1971, issue of the Technology Review published by the Alumni Association of the Massachusetts Institute of Technology.

Frisch, R. (1933). Editor's Note. Econometrica, 1(1), 1-4.

Fulton, L., Cazzola, P., \& Cuenot, F. (2009). IEA Mobility Model (MoMo) and its use in the ETP 2008. Energy Policy, 37(10), 3758-3768. https://doi.org/10.1016/j.enpol.2009.07.065

Garcia, R. (2007). Modeling vehicle choice behavior using agent-based approach. Presented at the Second Workshop on agent-based models of market dynamics and consumer behaviour 2007.

Gärling, T. (1992). The importance of routines for the performance of everyday activities. Scandinavian Journal of Psychology, 33(2), 170-177. https://doi.org/10.1111/j.1467-9450.1992.tb00896.x

Gilbert, C. L. (1986). PRACTITIONERS' CORNER: Professor Hendry’s Econometric Methodology. Oxford Bulletin of Economics and Statistics, 48(3), 283-307. https://doi.org/10.1111/j.1468-0084.1986.mp48003007.x 
Gilbert, G. N. (2008). Agent-based models. Los Angeles: Sage Publications.

Glerum, A., Stankovikj, L., Thémans, M., \& Bierlaire, M. (2014). Forecasting the Demand for Electric Vehicles: Accounting for Attitudes and Perceptions. Transportation Science, 48(4), 483-499. https://doi.org/10.1287/trsc.2013.0487

Gnann, T. (2015). Market Diffusion of Plug-in Electric Vehicles and Their Charging Infrastructure. Fraunhofer Verlag.

Gnann, T., Plötz, P., Funke, S., \& Wietschel, M. (2015). What is the market potential of plug-in electric vehicles as commercial passenger cars? A case study from Germany. Transportation Research Part D: Transport and Environment, 37, 171-187. https://doi.org/10.1016/j.trd.2015.04.015

Golder, P. N., \& Tellis, G. J. (1997). Will It Ever Fly? Modeling the Takeoff of Really New Consumer Durables. Marketing Science, 16(3), 256-270. https://doi.org/10.1287/mksc.16.3.256

Graham-Rowe, E., Gardner, B., Abraham, C., Skippon, S., Dittmar, H., Hutchins, R., \& Stannard, J. (2012). Mainstream consumers driving plug-in battery-electric and plug-in hybrid electric cars: A qualitative analysis of responses and evaluations. Transportation Research Part A: Policy and Practice, 46(1), 140-153. https://doi.org/10.1016/j.tra.2011.09.008

Grahn, M., Azar, C., Williander, M. I., Anderson, J. E., Mueller, S. A., \& Wallington, T. J. (2009). Fuel and Vehicle Technology Choices for Passenger Vehicles in Achieving Stringent $\mathrm{CO}_{2}$ Targets: Connections between Transportation and Other Energy Sectors. Environmental Science \& Technology, 43(9), 3365-3371. https://doi.org/10.1021/es802651r

Griliches, Z. (1986). Chapter 25 Economic data issues. In Zvi Griliches and Michael D. Intriligator (Ed.), Handbook of Econometrics (Vol. Volume 3, pp. 1465-1514). 
Elsevier. Retrieved from

http://www.sciencedirect.com/science/article/pii/S1573441286030052

Gül, T., Kypreos, S., Turton, H., \& Barreto, L. (2009). An energy-economic scenario analysis of alternative fuels for personal transport using the Global Multiregional MARKAL model (GMM). Energy, 34(10), 1423-1437. https://doi.org/10.1016/j.energy.2009.04.010

Haavelmo, T. (1944). The Probability Approach in Econometrics. Econometrica, 12, iii115. https://doi.org/10.2307/1906935

Harberger, A. C. (1962). The Incidence of the Corporation Income Tax. Journal of Political Economy, 70 (3), 215-240.

Hensher, D. A., Beck, M. J., \& Rose, J. M. (2011). Accounting for Preference and Scale Heterogeneity in Establishing Whether it Matters Who is Interviewed to Reveal Household Automobile Purchase Preferences. Environmental and Resource Economics, 49(1), 1-22. https://doi.org/10.1007/s10640-010-9420-3

Herbst, A., Toro, F., Reitze, F., \& Jochem, E. (2012). Introduction to energy systems modelling. Swiss Journal of Economics and Statistics, 148(2), 111-135.

Hewitt, C. (1977). Viewing control structures as patterns of passing messages. Artificial Intelligence, 8(3), 323-364. https://doi.org/10.1016/0004-3702(77)90033-9

Higgins, A., Paevere, P., Gardner, J., \& Quezada, G. (2012). Combining choice modelling and multi-criteria analysis for technology diffusion: An application to the uptake of electric vehicles. Technological Forecasting and Social Change, 79(8), 1399-1412. https://doi.org/10.1016/j.techfore.2012.04.008

Hoover, K. D. (2005). The Methodology of Econometrics (SSRN Scholarly Paper No. ID 728683). Rochester, NY: Social Science Research Network. Retrieved from http://papers.ssrn.com/abstract=728683 
Horne, M., Jaccard, M., \& Tiedemann, K. (2005). Improving behavioral realism in hybrid energy-economy models using discrete choice studies of personal transportation decisions. Energy Economics, 27(1), 59-77. https://doi.org/10.1016/j.eneco.2004.11.003

Hourcade, J.-C., Jaccard, M., Bataille, C., \& Ghersi, F. (2006). Hybrid Modeling: New Answers to Old Challenges Introduction to the Special Issue of "The Energy Journal.” The Energy Journal, 27, 1-11.

IEA (International Energy Agency). (2016a). Energy Technology Perspectives 2016.

Paris, France. Retrieved from http://www.iea.org/bookshop/719-

Energy_Technology_Perspectives_2016

IEA (International Energy Agency). (2016b). Global EV Outlook 2016. Paris, France.

Retrieved from

https://www.iea.org/publications/freepublications/publication/Global_EV_Outlo ok_2016.pdf

Intriligator, M. D. (1983). Chapter 3 Economic and econometric models. In Zvi

Griliches and Michael D. Intriligator (Ed.), Handbook of Econometrics (Vol. Volume 1, pp. 181-221). Elsevier. Retrieved from http://www.sciencedirect.com/science/article/pii/S1573441283010077

IPCC (Intergovernmental Panel on Climate Change). (2014). Climate Change 2014, synthesis report. Geneva, Switzerland. Retrieved from https://www.ipcc.ch/pdf/assessmentreport/ar5/syr/SYR_AR5_FINAL_full_wcover.pdf

Jensen, A. F., Cherchi, E., \& Mabit, S. L. (2013). On the stability of preferences and attitudes before and after experiencing an electric vehicle. Transportation 
Research Part D: Transport and Environment, 25, 24-32.

https://doi.org/10.1016/j.trd.2013.07.006

Jensen, A. F., Cherchi, E., Mabit, S. L., \& Ortúzar, J. de D. (2016). Predicting the Potential Market for Electric Vehicles. Transportation Science. https://doi.org/10.1287/trsc.2015.0659

Jeon, S. Y. (2010). Hybrid \& electric vehicle technology and its market feasibility. Cambridge: Massachusetts Institute of Technology.

Jochem. (2013). Platzhalter.

Jong, G. D., Fox, J., Daly, A., Pieters, M., \& Smit, R. (2004). Comparison of car ownership models. Transport Reviews, 24(4), 379-408. https://doi.org/10.1080/0144164032000138733

Kahneman, D., \& Tversky, A. (2000). Choices, Values, and Frames. Cambridge University Press.

Karplus, V. J., Paltsev, S., \& Reilly, J. M. (2010). Prospects for plug-in hybrid electric vehicles in the United States and Japan: A general equilibrium analysis. Transportation Research Part A: Policy and Practice, 44(8), 620-641. https://doi.org/10.1016/j.tra.2010.04.004

Kay, D., Hill, N., \& Newman, D. (2013). Powering Ahead - The future of low-carbon cars and fuels (p. 176). London: UK Pia and RAC Foundation. Retrieved from http://www.racfoundation.org/assets/rac_foundation/content/downloadables/pow ering_ahead-kay_et_al-apr2013.pdf

Keith, D. R. (2012). Essays on the dynamics of alternative fuel vehicle adoption: insights from the market for hybrid-electric vehicles in the United States (Thesis). Massachusetts Institute of Technology. Retrieved from http://dspace.mit.edu/handle/1721.1/79546 
Ketelaer, T., Kaschub, T., Jochem, P., \& Fichtner, W. (2014). The potential of carbon dioxide emission reductions in German commercial transport by electric vehicles. International Journal of Environmental Science and Technology, 11(8), 2169-2184. https://doi.org/10.1007/s13762-014-0631-y

Kieckhäfer, K. (2013). Marktsimulation zur strategischen Planung von Produktportfolios: Dargestellt am Beispiel innovativer Antriebe in der Automobilindustrie. Wiesbaden: Springer-Verlag.

Kieckhäfer, K., Volling, T., \& Spengler, T. S. (2014). A Hybrid Simulation Approach for Estimating the Market Share Evolution of Electric Vehicles. Transportation Science, 48(4), 651-670. https://doi.org/10.1287/trsc.2014.0526

Kiesling, E., Günther, M., Stummer, C., \& Wakolbinger, L. M. (2012). Agent-based simulation of innovation diffusion: a review. Central European Journal of Operations Research, 20(2), 183-230. https://doi.org/10.1007/s10100-0110210-y

Koopmans, T. C. (1949). Identification Problems in Economic Model Construction. Econometrica, 17(2), 125-144. https://doi.org/10.2307/1905689

Krail, M. (2009). System-Based Analysis of Income Distribution Impacts on Mobility Behaviour. Baden-Baden: Nomos.

Krupa, J. S., Rizzo, D. M., Eppstein, M. J., Brad Lanute, D., Gaalema, D. E., Lakkaraju, K., \& Warrender, C. E. (2014). Analysis of a consumer survey on plug-in hybrid electric vehicles. Transportation Research Part A: Policy and Practice, 64, 1431. https://doi.org/10.1016/j.tra.2014.02.019

Lane, B., \& Potter, S. (2007). The adoption of cleaner vehicles in the UK: exploring the consumer attitude-action gap. Journal of Cleaner Production, 15(11-12), 10851092. https://doi.org/10.1016/j.jclepro.2006.05.026 
Lévay, P. Z., Drossinos, Y., \& Thiel, C. (2017). The effect of fiscal incentives on market penetration of electric vehicles: A pairwise comparison of total cost of ownership. Energy Policy, 105, 524-533. https://doi.org/10.1016/j.enpol.2017.02.054

Lieven, T., Mühlmeier, S., Henkel, S., \& Waller, J. F. (2011). Who will buy electric cars? An empirical study in Germany. Transportation Research Part D: Transport and Environment, 16(3), 236-243. https://doi.org/10.1016/j.trd.2010.12.001

Loewenstein, G. (1996). Out of Control: Visceral Influences on Behavior. Organizational Behavior and Human Decision Processes, 65(3), 272-292. https://doi.org/10.1006/obhd.1996.0028

Lopes, M. M., Moura, F., \& Martinez, L. M. (2014). A rule-based approach for determining the plausible universe of electric vehicle buyers in the Lisbon Metropolitan Area. Transportation Research Part A: Policy and Practice, 59, 22-36. https://doi.org/10.1016/j.tra.2013.09.009

Martinez-Moyano, I. J. (2012). Documentation for model transparency. System Dynamics Review, 28(2), 199-208. https://doi.org/10.1002/sdr.1471

McCollum, D. L., Wilson, C., Pettifor, H., Ramea, K., Krey, V., Riahi, K., ... Fujisawa, S. (2016). Improving the behavioral realism of global integrated assessment models: An application to consumers' vehicle choices. Transportation Research Part D: Transport and Environment. https://doi.org/10.1016/j.trd.2016.04.003

McCollum, D., Yang, C., Yeh, S., \& Ogden, J. (2012). Deep greenhouse gas reduction scenarios for California - Strategic implications from the CA-TIMES energyeconomic systems model. Energy Strategy Reviews, 1(1), 19-32. https://doi.org/10.1016/j.esr.2011.12.003 
McFadden, D. (2000). Economic Choices, Nobel Prize Lecture. AM. ECON. REV., 91, 351.

McManus, W., \& Senter, R. (2009). Market Models for Predicting PHEV Adoption and Diffusion (Technical Challenges of Plug-In Hybrid Electric Vehicles and Impacts to the U.S. Power System) (p. 32). Ann Arbor: University of Michigan. Retrieved from https://deepblue.lib.umich.edu/bitstream/handle/2027.42/64436/102399.pdf;sequ ence $=1$

Meadows, D. H. (1972). Limits to Growth. Signet.

Meyer, G. (2009). Analyse und technisch-ökonomische Bewertung von Gesetzesfolgen im Individualverkehr: dargestellt am Beispiel der Automobilindustrie Japans und Deutschlands.

Miller, R. E., \& Blair, P. D. (2009). Input-output analysis: foundations and extensions (2nd ed.). Englangd: Cambridge University Press.

Mock, P., Hülsebusch, D., Ungethüm, J., \& Schmid, S.A. (2010). Electric vehicles - A model based assessment of future market prospects and environmental impacts, $1(3), 172-185$.

Moons, I., \& De Pelsmacker, P. (2012). Emotions as determinants of electric car usage intention. Journal of Marketing Management, 28(3-4), 195-237. https://doi.org/10.1080/0267257X.2012.659007

Morgan. (2008). The History of Econometric Ideas (Auflage: Revised.). Cambridge England; New York: Cambridge University Press.

Morgenstern, O. (1965). On Accuracy of Economic Observations (2nd Revised edition edition). Princeton, N.J: Princeton University Press. 
Noppers, E. H., Keizer, K., Bolderdijk, J. W., \& Steg, L. (2014). The adoption of sustainable innovations: Driven by symbolic and environmental motives. Global Environmental Change, 25, 52-62.

https://doi.org/10.1016/j.gloenvcha.2014.01.012

Pagan, A. (1987). Three Econometric Methodologies: A Critical Appraisal1. Journal of Economic Surveys, 1(1-2), 3-23. https://doi.org/10.1111/j.14676419.1987.tb00022.x

Pasaoglu, G., Harrison, G., Jones, L., Hill, A., Beaudet, A., \& Thiel, C. (2016). A system dynamics based market agent model simulating future powertrain technology transition: Scenarios in the EU light duty vehicle road transport sector. Technological Forecasting and Social Change, 104, 133-146. https://doi.org/10.1016/j.techfore.2015.11.028

Peters, A., \& Dütschke, E. (2014). How do Consumers Perceive Electric Vehicles? A Comparison of German Consumer Groups. Journal of Environmental Policy \& Planning, 16(3), 359-377. https://doi.org/10.1080/1523908X.2013.879037

Peters, A., Gutscher, H., \& Scholz, R. W. (2011). Psychological determinants of fuel consumption of purchased new cars. Transportation Research Part F: Traffic Psychology and Behaviour, 14(3), 229-239. https://doi.org/10.1016/j.trf.2011.01.003

Pfahl, S., Jochem, P., \& Fichtner, W. (2013). When Will Electric Vehicles Capture the German Market? And why? Presented at the Electric Vehicle Symposium 27, Barcelona.

Pietzcker, R. C., Longden, T., Chen, W., Fu, S., Kriegler, E., Kyle, P., \& Luderer, G. (2014). Long-term transport energy demand and climate policy: Alternative 
visions on transport decarbonization in energy-economy models. Energy, 64, 95-108. https://doi.org/10.1016/j.energy.2013.08.059

Plötz, P. (2011). Uncertainty in Diffusion of Competing Technologies and Application to Electric Vehicles. Working Paper Sustainability and Innovation, 12, 1-22. Plötz, P., Schneider, U., Globisch, J., \& Dütschke, E. (2014). Who will buy electric vehicles? Identifying early adopters in Germany. Transportation Research Part A: Policy and Practice, 67, 96-109. https://doi.org/10.1016/j.tra.2014.06.006

Potoglou, D., \& Kanaroglou, P. S. (2008). Disaggregate Demand Analyses for Conventional and Alternative Fueled Automobiles: A Review. International Journal of Sustainable Transportation, 2(4), 234-259. https://doi.org/10.1080/15568310701230398

Propfe, B., Kreyenberg, D., Wind, J., \& Schmid, S. (2013). Market penetration analysis of electric vehicles in the German passenger car market towards 2030. International Journal of Hydrogen Energy, 38(13), 5201-5208. https://doi.org/10.1016/j.ijhydene.2013.02.049

Purwanto, A. J. (2013). MOVEET - MObility, Vehicle fleet, Energy use and Emissions forecast Tool.

Rahmandad, H., \& Sterman, J. D. (2012). Reporting guidelines for simulation-based research in social sciences. System Dynamics Review, 28(4), 396-411. https://doi.org/10.1002/sdr.1481

Rai, V., \& Henry, A. D. (2016). Agent-based modelling of consumer energy choices. Nature Climate Change, 6(6), 556-562. https://doi.org/10.1038/nclimate2967

Rand, W., Herrmann, J., Schein, B., \& Vodopivec, N. (2015). An Agent-Based Model of Urgent Diffusion in Social Media. Journal of Artificial Societies and Social Simulation, 18(2). https://doi.org/10.18564/jasss.2616 
Raveau, S., Yáñez, M. F., \& Ortúzar, J. de D. (2012). Practical and empirical identifiability of hybrid discrete choice models. Transportation Research Part B: Methodological, 46(10), 1374-1383. https://doi.org/10.1016/j.trb.2012.06.006

Rezvani, Z., Jansson, J., \& Bodin, J. (2015). Advances in consumer electric vehicle adoption research: A review and research agenda. Transportation Research Part D: Transport and Environment, 34, 122-136. https://doi.org/10.1016/j.trd.2014.10.010

Richardson, G. P. (2011). Reflections on the foundations of system dynamics: Foundations of System Dynamics. System Dynamics Review, 27(3), 219-243. https://doi.org/10.1002/sdr.462

Romilly, P., Song, H., \& Liu, X. (1998). Modelling and forecasting car ownership in Britain: a cointegration and general to specific approach. Journal of Transport Economics and Policy, 165-185.

Sampson, M. (2013). General Equilibrium with Imperfect Competition. Retrieved from http://www.loglinear.com/wpcontent/uploads/2013/09/CournotSeptember06.pdf

Schade, W. (2005). Strategic Sustainability Analysis: Concept and application for the assessment of European Transport Policy (Auflage: 1). Baden-Baden: Nomos.

Schäfer, A., \& Jacoby, H. D. (2006). Vehicle technology under CO2 constraint: a general equilibrium analysis. Energy Policy, 34(9), 975-985. https://doi.org/10.1016/j.enpol.2004.08.051

Schmelzer, S., \& Miess, M. (2015). The Economic Costs of Electric Vehicles.

Schuitema, G., Anable, J., Skippon, S., \& Kinnear, N. (2013). The role of instrumental, hedonic and symbolic attributes in the intention to adopt electric vehicles. 
Transportation Research Part A: Policy and Practice, 48, 39-49.

https://doi.org/10.1016/j.tra.2012.10.004

Schwoon, M. (2006). Simulating the adoption of fuel cell vehicles. Journal of Evolutionary Economics, 16(4), 435-472. https://doi.org/10.1007/s00191-006$0026-4$

Shafiei, E., Thorkelsson, H., Ásgeirsson, E. I., Davidsdottir, B., Raberto, M., \& Stefansson, H. (2012). An agent-based modeling approach to predict the evolution of market share of electric vehicles: A case study from Iceland. Technological Forecasting and Social Change, 79(9), 1638-1653. https://doi.org/10.1016/j.techfore.2012.05.011

Shay, C. L., DeCarolis, J., Gage, C., Yeh, S., \& E.L., W. (2006). EPA U.S. National MARKAL Database Documentation. Research Triangle Park, NC.: U.S. Environmental Protection Agency.

Shepherd, S., Bonsall, P., \& Harrison, G. (2012). Factors affecting future demand for electric vehicles: A model based study. Transport Policy, 20, 62-74. https://doi.org/10.1016/j.tranpol.2011.12.006

Shoven, J. B., \& Whalley, J. (1984). Applied General-Equilibrium Models of Taxation and International Trade: An Introduction and Survey. Journal of Economic Literature, 22(3), 1007-1051.

Skippon, S., \& Garwood, M. (2011). Responses to battery electric vehicles: UK consumer attitudes and attributions of symbolic meaning following direct experience to reduce psychological distance. Transportation Research Part D: Transport and Environment, 16(7), 525-531. https://doi.org/10.1016/j.trd.2011.05.005 
Spanos, A. (1999). Probability Theory and Statistical Inference: Econometric Modeling with Observational Data. Cambridge, UK; New York, NY, USA: Cambridge University Press.

Stephan, C., \& Sullivan, J. (2009). An agent-based hydrogen vehicle/infrastructure model. In Proceedings of the 2004 Congress on Evolutionary Computation (IEEE Cat. No.04TH8753). Institute of Electrical \& Electronics Engineers (IEEE). https://doi.org/10.1109/cec.2004.1331110

Stephens, T. (2010). An Agent-Based Model of Energy Demand and Emissions From Plug-In Hybrid Electric Vehicle Use.

Sterman, J. D. (2000). Business Dynamics: Systems Thinking and Modeling for a Complex World. McGraw-Hill/Irwin.

Struben, J., \& Sterman, J. D. (2008). Transition challenges for alternative fuel vehicle and transportation systems. Environment and Planning B: Planning and Design.

Sullivan, J. L., Salmeen, I., \& Simon, C. (2009). PHEV marketplace penetration: An agent based simulation.

Svenson, O. (1979). Process descriptions of decision making. Organizational Behavior and Human Performance, 23(1), 86-112. https://doi.org/10.1016/00305073(79)90048-5

Sycara, K. P. (1998). Multiagent systems. AI Magazine, 19(2), 79-92.

Tinbergen, J. (1937). An econometric approach to business cycle problems. Retrieved from http://agris.fao.org/agris-search/search.do?recordID=US201300606041

Train, K. (1986). Qualitative choice analysis: Theory, econometrics, and an application to automobile demand (Vol. 10). Cambridge, Massachusetts. 
Verhulst, P. F. (1838). Notice sur la loi que la population suit dans son accroissement. Correspondance Mathematique et Physique Publiee par A. Quetelet, 10, 113121.

Vij, A., \& Walker, J. L. (2016). How, when and why integrated choice and latent variable models are latently useful. Transportation Research Part B: Methodological, 90, 192-217. https://doi.org/10.1016/j.trb.2016.04.021

Vliet, O. van, Vries, B. de, Faaij, A., Turkenburg, W., \& Jager, W. (2010). Multi-agent simulation of adoption of alternative fuels. Transportation Research Part D: Transport and Environment, 15(6), 326-342. https://doi.org/10.1016/j.trd.2010.03.006

Walther, G., Wansart, J., Kieckhäfer, K., Schnieder, E., \& Spengler, T. S. (2010). Impact assessment in the automotive industry: mandatory market introduction of alternative powertrain technologies. System Dynamics Review, 26(3), 239-261. https://doi.org/10.1002/sdr.453

Wansart, J. (2012). Analyse von Strategien der Automobilindustrie zur Reduktion von CO2-Flottenemissionen und zur Markteinführung Alternativer Antriebe: Ein . . . (2012th ed.). Wiesbaden: Springer Gabler.

Weikl, R. (2010). Simulationen zur Abschätzung der Marktanteilsentwicklung unterschiedlicher Antriebsvarianten am deutschen Fahrzeugmarkt: Ein systemdynamisches Modell zur Entschediungsunterstützung in der strategischen Marktanalyse (1st ed.). Chemnitz: GUC Gesellschaft f. Unternehmensrechnung u. Controlling.

Wooldridge, M., \& Jennings, N. R. (1995). Intelligent agents: theory and practice. The Knowledge Engineering Review, 10(2), 115. https://doi.org/10.1017/S0269888900008122 
Yeh, S., Farrell, A., Plevin, R., Sanstad, A., \& Weyant, J. (2008). Optimizing U.S. Mitigation Strategies for the Light-Duty Transportation Sector: What We Learn from a Bottom-Up Model. Environmental Science \& Technology, 42(22), 82028210. https://doi.org/10.1021/es8005805

Zhang, H., \& Vorobeychik, Y. (2016). Empirically Grounded Agent-Based Models of Innovation Diffusion: A Critical Review. CoRR, abs/1608.08517. Retrieved from http://arxiv.org/abs/1608.08517

Zhang, Y., Yu, Y., \& Zou, B. (2011). Analyzing public awareness and acceptance of alternative fuel vehicles in China: The case of EV. Energy Policy, 39(11), 70157024. https://doi.org/10.1016/j.enpol.2011.07.055 